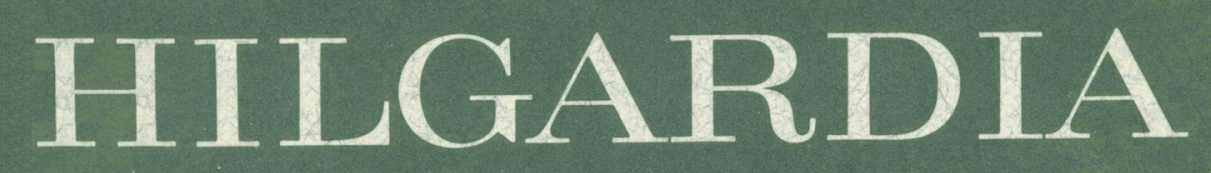

AJOURNAL OF AGRICULTURAL SCIENCE PUBLISHED BY THE CALIFORNIA AGRICULTURALEXPERIMENT STATION

Volume 40, Number $13 \cdot$ January, 1971

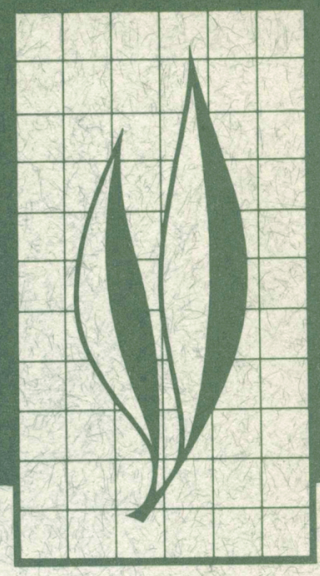

\title{
Developmental Anatomy of Major Lateral Leaf Veins of Healthy and of Pear-decline Diseased Pear Trees
}

Kengo Soma and Henry Schneider 


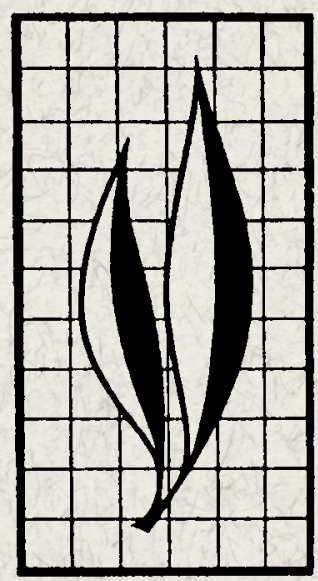

The developmental anatomies of healthy and of pear-decline affected major lateral leaf veins of Pyrus sp. 'Variolosa' are described and compared.

Following the initiation of a leaf primordium in a healthy plant, the marginal meristems initiate the wings of the lamina. A superficial sheet of anticlinally dividing cells gives rise to the protoderm. Submarginally, a uniseriate strand of initial cells gives rise by anticlinal divisions to the adaxial and abaxial subprotodermal layers, and by periclinal divisions to the middle layer. The abaxial subprotoderm, by periclinal divisions, also contributes cells to the middle layer.

The procambia that give rise to lateral veins differentiate from undifferentiated cells in the middle layer. Sieve tubes that form in the primary phloem are arranged somewhat irregularly, and companion cells, if present, cannot be distinguished with certainty

Continued on inside back cover

\section{THE AUTHORS:}

Kengo Soma was Visiting Assistant Plant Pathologist, Department of Plant Pathology, University of California, Riverside, from April 1,1967 , to March 30,1968. He is a member of the teaching and research staff in the Department of Botany, Faculty of Science, Tokyo Kyoiku University, Otsuka, Tokyo, Japan.

Henry Schneider is Plant Pathologist and Lecturer, Department of Plant Pathology, University of California, Riverside.

The authors are indebted to Peter J. Sasaki for assistance with photography and preparation of the plates. 


\title{
Developmental Anatomy of Major Lateral Leaf Veins of Healthy and of Pear-decline Diseased Pear Trees ${ }^{1}$
}

\begin{abstract}
Following the initiation of a leaf primordium in healthy Pyrus sp. 'Variolosa, the marginal meristems initiate the wings of the lamina. A superficial sheet of anticlinally dividing cells gives rise to the protoderm. Submarginally, a uniseriate strand of initial cells gives rise by anticlinal divisions to the adaxial and abaxial subprotodermal layers, and by periclinal divisions to the middle layer. The abaxial subprotoderm, by periclinal divisions, also contributes cells to the middle layer.

The procambia that give rise to lateral veins differentiate from undifferentiated cells in the middle layer. Sieve tubes that form in the primary phloem from the procambium are arranged somewhat irregularly, while the cambium produces radially arranged rows of secondary phloem.

In trees affected by pear decline necrosis does not occur in the primary phloem of new shoots that form following chilling; possibly they are pathogen free. Sieve-tube necrosis in secondary phloem is accompanied by excessive and prolonged abnormal phloem formation, and groups of sieve tubes in this abnormal phloem also become necrotic. The necrotic process consists of degeneration of organelles, membranes, and ground cytoplasm.
\end{abstract}

\section{INTRODUCTION}

A cultivar of Pyrus designated 'Variolosa' was distributed for use as a blightresistant rootstock by F. C. Reimer $;^{2}$ he realized that the cultivar was not the species $P$. variolosa Wall that is synonymous with $P$. Pashia Beech-Ham (Reimer, 1925; Rehder, 1927). The Reimer cultivar, Pyrus sp. 'Variolosa,' is a moderately good test plant for pear decline under greenhouse conditions (Tsao, Schneider, and Kaloostian, 1966; Schneider, 1970). Leaves on some branches that are graft- or psyllainoculated during any one growing season may develop brown, and sometimes rusty-appearing, major lateral veins during that season. The next season following winter chilling, apparently normal branches grow out, but growth terminates a little sooner than that of control trees, possibly because the root system is poor. After leaves expand to full size, they become thicker and more leathery than leaves of control plants. When the leaves are several months old, the major lateral veins become brown. During each successive season, the trees become weaker, and the amount of new growth following winter chilling becomes less (figs. 1 and 2 ). The internodes of stems produced during erratic second or third growth flushes reckoned from the time of chilling may not elongate, especially if the plants are grown two years without chilling; the resulting shoots appear as tufts of leaves. Sections of brown lateral veins reveal sieve-tube necrosis, hyperactivity of the cambium, and excessive phloem formation (Tsao and Schneider 1967).

\footnotetext{
${ }^{1}$ Submitted for publication February 18, 1970.

2 Formerly superintendent of the Southern Oregon Branch Experiment Station.
} 


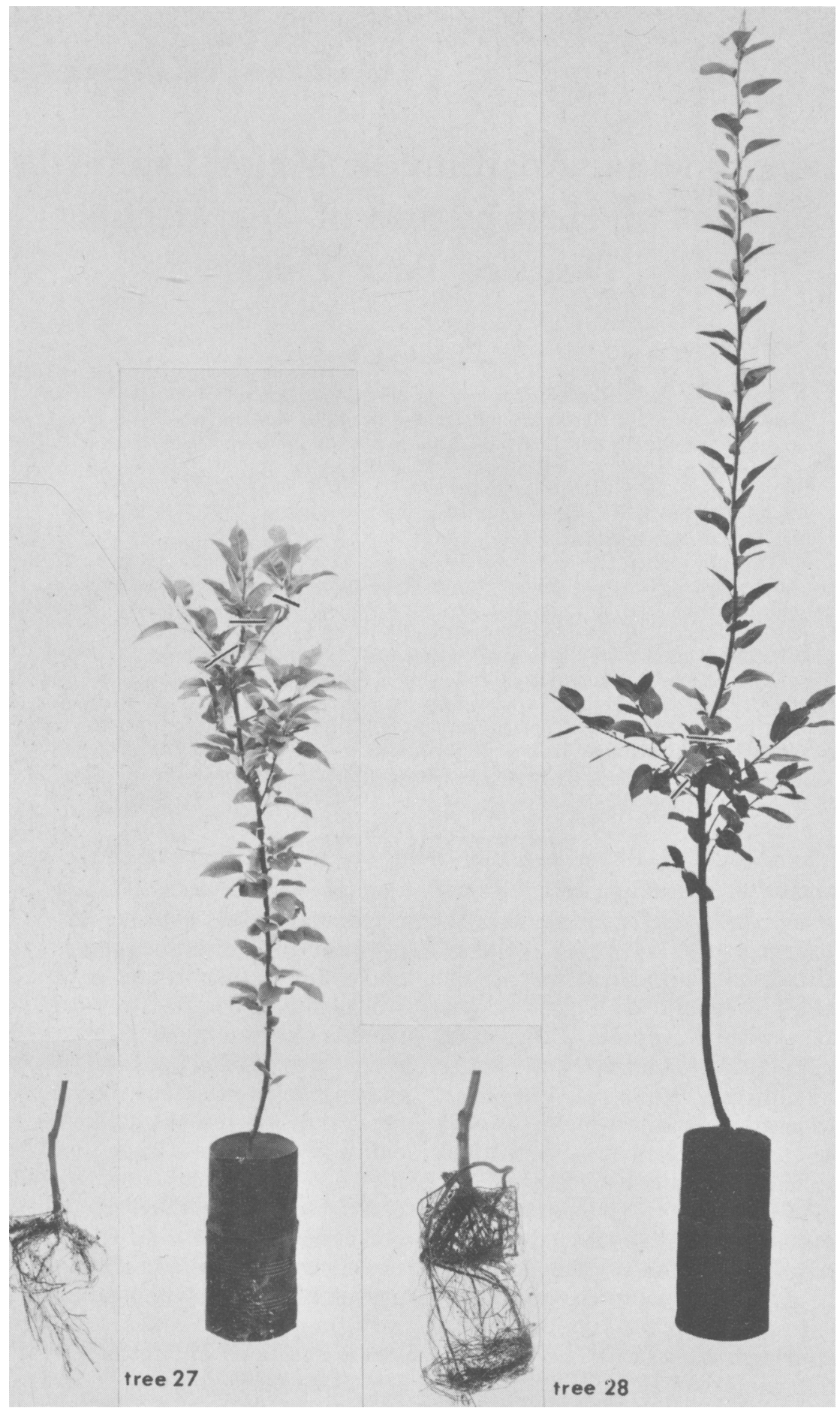

Fig. 1. Tree 27 (pear decline-infected) and tree 28 (pear-decline-free) and their roots as they appeared on April 24, 1968. The new growth was produced during a three-month period that followed dormancy chilling and the pruning of 6 feet of stem off the top of tree 28 (but none from tree 27). Black lines across the branches indicate where the 1968 shoot growth began. Note the sparcity of roots on tree 27 . See table 1 , experiment 72 , for further information. $(\times 0.08$.) 


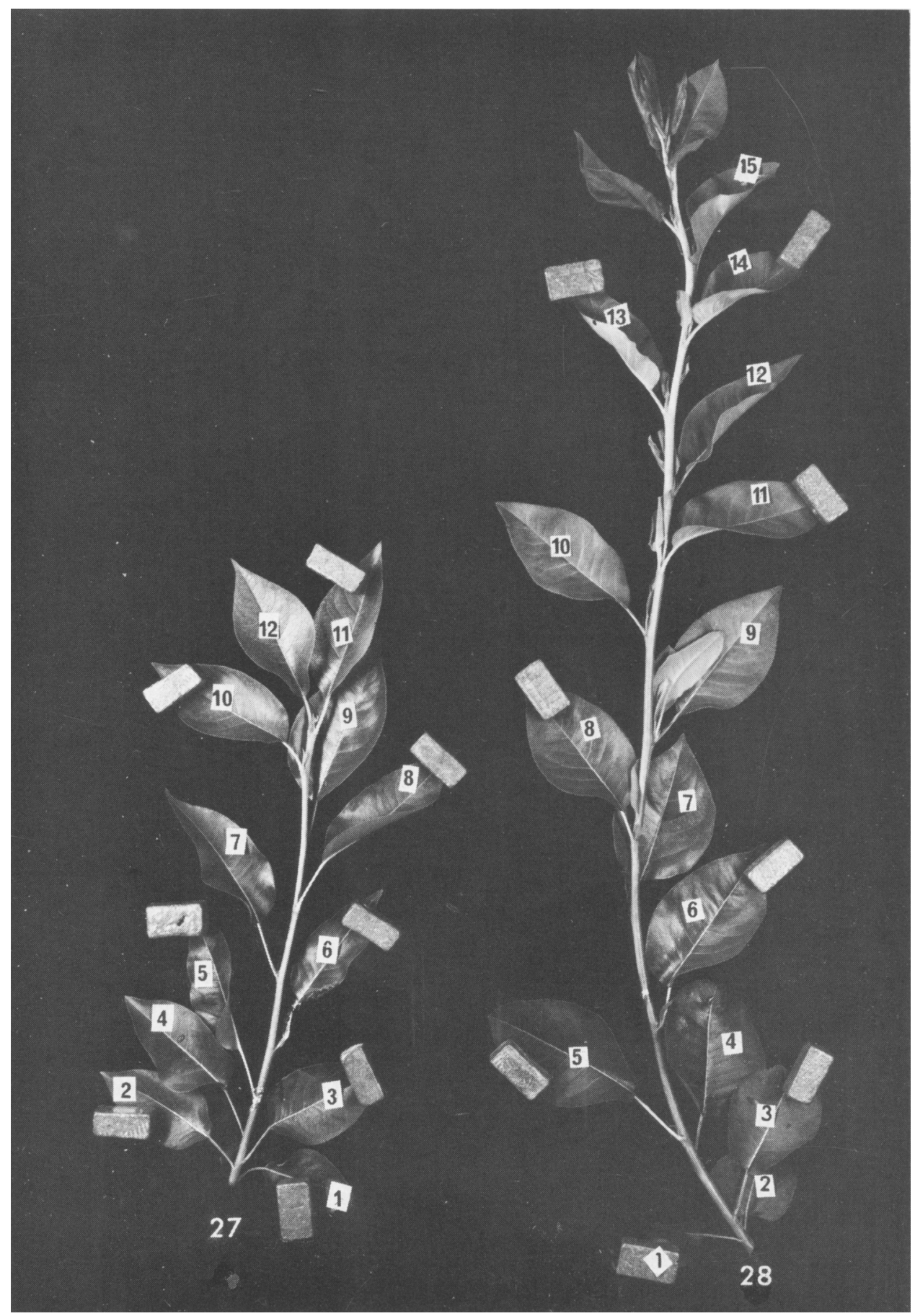

Fig. 2. Branches from infected tree 27, and healthy tree 28, experiment 72, on May 26, 1967. Tissue collection 301 was made from these branches. Hereafter, form used will be infected $72: 27$ (301) or healthy $72: 28$ (301). The growth was made during a 44-day period that followed chilling. In this and all other collections, leaves were numbered beginning with the oldest and first formed on the elongating shoot and proceeded acropetally. Growing apexes with small leaves and unelongated internodes were collected as one piece (e.g., apex of 28). Major lateral veins from older leaves of various ages were individually collected. The branch from tree 27 had ceased growing, and its oldest leaves gave a strong test for starch (table 1$).(\times 0.27$.) 
The secondary sieve tubes of diseased veins contain mycoplasma-like bodies (Hibino and Schneider, 1970), and they presumably cause pear decline; but at the time of writing this paper, this has not been proved.

This work is being published subsequently to observing the association of mycoplasma-like bodies with pear decline, because it is comprehensive and required a long time to prepare. However, research reported herein was done previous to the discovery of mycoplasma, and a different aspect of the pathology is reported. Furthermore, these studies served as a basis for finding the mycoplasma-like bodies. That such bodies are associated with yellowstype disease was not generally known during the course of this work, and pathogenicity of mycoplasma-like bodies in plants is yet to be proved.

This paper reports on a study of the ontogeny of the major lateral veins of healthy Pyrus sp. 'Variolosa' and the sequence of degenerative changes in the developing major lateral veins of leaves from pear decline-diseased trees.

\section{REVIEW OF LITERATURE}

\section{Histogenesis of the leaf and of lateral veins}

In many Dicotyledons, development of the leaf may be divided in three stages: (1) formation of the foliar buttress, (2) formation of the leaf axis, and (3) formation of the lamina (Esau, 1965). The lamina is initiated from two bands of meristematic cells called marginal meristems located along the two circumferential sides of the leaf primordium (Foster, 1936).

The cells on the edge of this meristem are the marginal initials; they give rise to the adaxial and abaxial protoderms by anticlinal divisions, which ultimately. differentiate into the adaxial and abaxial epidermi.

The internal tissues of the leaf may be traced to the activity of a strand of submarginal initials. Foster (1936) recognized two distinct types of behavior of the submarginal initials. In type one, as represented by Nicotiana tabacum (Avery, 1933), the submarginal initial divides anticlinally to form the adaxial and abaxial subprotodermal layers, as well as periclinally to form the middle layer. In type two, as shown by Carya buckleyi var. arkansana, the submarginal initials divide anticlinally giving rise alternately to the adaxial or the abaxial subprotodermal layers. The middle layer in turn is formed by periclinal divisions of cells at a varying distance from the margin in the abaxial subprotodermal layer (Foster, 1935). Later, some investigators reported that the middle layer forms from the adaxial subprotodermal layer in some species (Gifford, 1951; Hara, 1957). However, there have been reports of combinations of patterns that occur in the formation of the internal layers of the differentiating lamina (Cross, 1937 and 1938; Gifford, 1951; Hara, 1958; Schneider, 1952).

As the lamina expands, vein procambia differentiate in the middle layer. The larger, lateral veins are initiated earlier and closer to the marginal meristem and from greater masses of tissue than are the smaller ones (Esau, 1965). Although there is a considerable literature dealing with the differentiation of the vein procambia in an expanding lamina, information on further development into the mature veins is meager. Usually protophloem precedes the protoxylem in maturation (Esau, 1965). The bundle sheath of some dicotyledons appears to originate in the ground meristem around the procambium, and bundle sheath extensions are formed from derivatives of abaxial and adaxial subprotodermal layers (Gifford, 1953).

A distinction may be made between 
the minor and the major veins of plants. The minor veins function primarily in the draining of assimilates from the mesophyll of photosynthesizing leaves and in supplying the mesophyll with water and mineral nutrients. They are highly specialized for these purposes and differ from the major veins in having a reduced amount of xylem and reduced phloem with very narrow sieve tubes. Also, there is no cambium intervening between xylem and phloem, and in some plants highly specialized transfer cells occur between the sieve tubes and the mesophyll-like bundle sheath (Esau, 1967; Gunning, Pate, and Briarty, 1968). The major veins are systematically arranged and act as a trunk line between the midvein and the minor veins. Perhaps they also serve to drain and supply materials to and from adjacent mesophyll cells. This paper is concerned with the development and structure of the major lateral veins.

Cambial activity is reported in major reins of some dicotyledonous leaves (Bond, 1942; Schneider, 1945a; Shtromberg, 1959). Sieve tubes in the secondary phloem are derived from sievetube mother cells which are arranged end to end in files. Each mother cell divides by one or more longitudinal walls with a large cell and one or more smaller ones resulting. The larger cell differentiates into a sieve element and the smaller shorter cells into companion cells. Upon maturation, the companion cell of plants may contain thick cytoplasm with small vacuoles, a large nucleus, many ribosomes and mitochondria, and plastids and dictyosomes (Duloy, Mercer, and Rathgeber 1961; Wooding and Northcote, 1965; Shih and Currier, 1969). The nature of the endoplasmic reticulum in companion cells of plants is of interest because it will be reported herein that massive amounts of it occur in pear leaves. Duloy, Mercer, and Rathgeber (1961) observed closely packed cytoplasmic membranes in the cytoplasm of compan- ion cells of Cucurbita pepo (Duchesne). Endoplasmic reticulums were not reported in presumed companion cells (Uebergangszellen) of minor veins of Beta (Esau, 1967), but electron micrographs of Nicotiana companion cells show considerable endoplasmic reticulum (fig. 8 in Esau and Cronshaw, 1967).

Differentiation of the sieve-tube element of plants involves a reduction in the amount of cytoplasm and organelles. The tonoplast and nucleus disintegrate and some of the organelles are dispersed into the "vacuole". The sievetube plastids are the largest of the organelles in the "vacuole" and are of a specialized nature (Esau, Cronshaw, and Hoefert, 1967). The sieve plates are formed in certain areas on the end walls by formation of callose-lined pores (Esau, Cheadle, and Risley, 1962; Shih and Currier, 1969). After maturation, the walls of the plate may become thickened by deposition of additional callose which tends to constrict the protoplasmic connections traversing the holes in the sieve-plate wall. When the sieve tubes become dormant, or as they degenerate, or as they respond to wounding and disease, the callose becomes further thickened.

\section{Classification of phloem diseases}

Based on the nature of the pathological anatomy, we have devised two tentative systems of classification of phloem diseases caused by agents such as viruses and mycoplasmas.

System 1 is contingent upon the kind of cells or phloem elements that first become affected when infection occurs (or, in the case of chronically infected trees, upon the invasion of newly formed shoots or roots by the causal agent). In this system the diseases are split into two groups. One of them embraces diseases that initially cause sieve-tube necrosis; some diseases in this group are leaf roll of potato, Solanum tuberosum (Quanjer, 1931); Western X (buck- 
TREATMENTS, SYMPTOMS EXPRESSED, AND DATES OF TISSU

\begin{tabular}{|c|c|c|c|c|c|c|c|c|}
\hline \multirow{3}{*}{$\begin{array}{l}\text { Number of } \\
\text { experiment }\end{array}$} & \multirow{2}{*}{ Item } & \multicolumn{3}{|c|}{1964} & \multicolumn{4}{|c|}{1965} \\
\hline & & Spring & Summer & Fall & Winter & Spring & Summer & Enter \\
\hline & Treatment:* & $\begin{array}{c}\text { Trees } \\
\text { budded } \\
\text { May 14 }\end{array}$ & $\begin{array}{l}\text { Psylla } \\
\text { inoc. } \\
J \text { uly } 28\end{array}$ & $\begin{array}{l}\text { C. R. } \dagger \\
\text { Dec. } 9\end{array}$ & $\underset{F \cdot \text { Geb. } 16}{\text { G. } \dagger}$ & & & $\begin{array}{l}\text { C. } \mathrm{H} . \\
\text { Nar. } 8\end{array}$ \\
\hline \multirow{3}{*}{38} & $\begin{array}{l}\text { Symptoms: } \dagger \\
\text { Tree } 2 \text { (infected) }\end{array}$ & & & $\underset{\text { Nov. } 2}{\text { B. }}++^{\dagger}$ & & $\underset{\text { May }}{\text { B. V. }}+\underset{+}{+}$ & $\underset{\text { July } 21}{\text { B. }}$ & B. \\
\hline & Tree 1 (control) $\S$ & & & & & & & \\
\hline & $\begin{array}{l}\text { Collection nos. and } \\
\text { dates: }\end{array}$ & & & & & & & \\
\hline \multirow{4}{*}{54} & Treatment:* & & & & $\underset{\text { rooted }}{\text { Cuttings }}$ & $\begin{array}{c}\text { Psylla } \\
\text { inoc. } \\
\text { June } 10\end{array}$ & & \\
\hline & $\begin{array}{l}\text { Symptoms: } \dagger \\
\text { Tree } 1 \text { (infected) }\end{array}$ & & & & & & $\begin{array}{l}\text { B. V. }- \\
\text { Aug. } 16\end{array}$ & B. \\
\hline & Tree 2 (control) $\S$ & & & & & & & \\
\hline & $\begin{array}{l}\text { Collection nos. and } \\
\text { dates: }\end{array}$ & & & & & & & \\
\hline \multirow{4}{*}{56} & Treatment:* & & & & $\begin{array}{l}\text { Cuttings } \\
\text { rooted }\end{array}$ & & $\begin{array}{l}\text { Psylla } \\
\text { inoc.** } \\
\text { July } 14\end{array}$ & $\begin{array}{l}\text { Ch. } \mathrm{H} \text {. } \\
\text { ar. }\end{array}$ \\
\hline & $\begin{array}{l}\text { Symptoms: } \dagger \\
\text { Tree } 1 \text { (infected) }\end{array}$ & & & & & & & $\begin{array}{l}\text { B. } \mathrm{y} \\
\text { Dect: }\end{array}$ \\
\hline & Tree 2 (control) $\S$ & & & & & & & \\
\hline & $\begin{array}{l}\text { Collection nos. and } \\
\text { dates }\end{array}$ & & & & & & & \\
\hline \multirow{4}{*}{72} & Treatment: & & & & & & & \\
\hline & $\begin{array}{l}\text { Symptoms: } \dagger \\
\text { Tree } 27 \text { (infected) }\end{array}$ & & & & & & & \\
\hline & Tree 28 (control)§ & & & & & & & \\
\hline & $\begin{array}{l}\text { Collection nos. and } \\
\text { dates: }\end{array}$ & & & & & & & \\
\hline
\end{tabular}

* Trees were pronagated from hard wood cuttings collected and rooted at Davis, California, except for trees in experime which were the Davis Variolosa grafted on Pyrus ussuriensis (seedlings). Infected trees were experimentally inoculated infectious psylla.

$\dagger$ Abbreviations are: C. R. = plants moved to cold room;G. H. = plants moved to greenhouse; $\mathbf{L}$. H. = plants moved house; B. V. $=$ absence or occurrence of brown veins, $-=$ none, $+=$ slight, $++=$ moderate, $+++=$ severe. In no control trees develop brown veins.

$\ddagger$ Starch tests: Leaf discs were cleared in AFA fixing solution, washed in water, and then placed in $\mathrm{I}_{2} \mathrm{KI}$. They gave the $f_{1}$ ing color-reaction intensities for starch: $-=$ none; $+=$ slight; $++=$ moderate; $+++=$ copious. 
SELLECTIONS FOR THE EXPERIMENTAL 'VARIOLOSA' TREES*

\begin{tabular}{|c|c|c|c|c|c|c|c|c|c|}
\hline \multicolumn{4}{|c|}{1966} & \multicolumn{4}{|c|}{1967} & \multicolumn{2}{|c|}{1968} \\
\hline Fallinter & Spring & Summer & Fall & Winter & Spring & Summer & Fall & Winter & Spring \\
\hline $\begin{array}{l}\text { C. Ft. H. } \\
\text { Tov. } 8 \text { r. } 8\end{array}$ & & & $\begin{array}{l}\text { L. H. } \dagger \\
\text { Oct. } 26\end{array}$ & $\begin{array}{l}\text { C. R. } \\
\text { Feb. } 24\end{array}$ & $\begin{array}{l}\text { G. H. } \\
\text { May } 18\end{array}$ & & & & \\
\hline $\begin{array}{l}\text { V.t- } \\
\text { Vov. }\end{array}$ & $\begin{array}{l}\text { B. V.++ } \\
\text { Vig. pale } \\
\text { June } 10\end{array}$ & B. V.+十+ & $\underset{\text { Oct. } 26}{\text { B. V.+1 }}$ & & 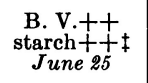 & B. V.t++ & & & \\
\hline 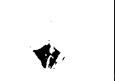 & $\begin{array}{c}\text { Tall } \\
\text { vigorous§ }\end{array}$ & & $\begin{array}{c}\text { Large } \\
\text { Vigorous }\end{array}$ & & Starch - & $\begin{array}{l}\text { Big tree. } \\
\text { Normal } \\
\text { foliage }\end{array}$ & & & \\
\hline & & & & & $\begin{array}{c}302 \\
\text { June } 9\end{array}$ & $\begin{array}{c}304 \\
\text { July } \\
305 \\
\text { July } 25\end{array}$ & & & \\
\hline & $\begin{array}{c}\text { Tree 2 } \\
\text { pruned }\end{array}$ & & $\begin{array}{l}\text { L. H. } \\
\text { Dec. } 1\end{array}$ & $\begin{array}{l}\text { C. R. } \\
\text { Feb. } 28\end{array}$ & & $\begin{array}{l}\text { G. H. } \\
\text { Pruned } \\
\text { July } 19\end{array}$ & & $\begin{array}{l}\text { L. H. } \\
\text { Jan. } 8 \\
\text { C. R. } \\
\text { Feb. } 2 s\end{array}$ & $\underset{A p r .29}{\text { L. H. }}$ \\
\hline : $_{\text {n. } 17}^{+t+}$ & $\underset{\text { June } 17}{\text { B. V. }}$ & $\begin{array}{c}\text { No recent } \\
\text { growth } \\
\text { Aug. } 21\end{array}$ & $\begin{array}{l}\text { B. V.- } \\
\text { Flowers } \\
\text { Dec. 1 }\end{array}$ & & & $\begin{array}{l}\text { B. V.- } \\
\text { Slight } \\
\text { growth } \\
\text { Sept. } 12\end{array}$ & $\begin{array}{l}\text { B. V.- } \\
\text { Severe } \\
\text { decline } \\
\text { Oct. } 31\end{array}$ & $\begin{array}{c}\text { B. V.t++ } \\
\text { Little } \\
\text { growth } \\
\text { Jan. } 8\end{array}$ & \\
\hline & $\begin{array}{l}\text { Tall } \\
\text { defoli- } \\
\text { ated }\end{array}$ & $\begin{array}{c}\text { Good } \\
\text { recent } \\
\text { growth }\end{array}$ & & & & $\begin{array}{c}\text { Good } \\
\text { growth }\end{array}$ & $\begin{array}{l}\text { Vigorous } \\
\text { growth }\end{array}$ & $\begin{array}{c}\text { Good } \\
\text { growth }\end{array}$ & \\
\hline : & & & & & & $\begin{array}{c}306 \\
\text { Aug. } 2 \\
307 \\
\text { Aug. } 15\end{array}$ & $\begin{array}{c}311 \\
\text { Nov. } 21\end{array}$ & & \\
\hline H. & & & $\begin{array}{l}\text { L. H. } \\
\text { Dec. } 1\end{array}$ & $\begin{array}{l}\text { C. R. } \\
\text { Feb. } 17\end{array}$ & & $\begin{array}{l}\text { G. H. } \\
\text { Aug. } 11\end{array}$ & & $\begin{array}{l}\text { L. H. } \\
\text { Jan. } 8 \\
\text { C. R. } \\
\text { Feb. } 29\end{array}$ & $\underset{A p r . \dot{\text { L }}}{\text { H. }}$ \\
\hline \multirow[t]{3}{*}{ 2) } & $\begin{array}{c}\text { B. V.+t+ } \\
\text { starch+ } \\
\text { June } 17\end{array}$ & $\begin{array}{c}\text { B. V. }+++ \\
\text { Leaves } \\
\text { in whorls } \\
\text { Aug. } 22\end{array}$ & B. $\underset{\text { Dec. } 1}{\mathrm{~V} .++}$ & & & $\begin{array}{l}\text { B. V.- } \\
\text { Fair } \\
\text { growth } \\
\text { Sept. 12 }\end{array}$ & $\begin{array}{l}\text { B. V. } \\
\text { Nov. } 1\end{array}$ & $\begin{array}{c}\text { B. V.- } \\
\text { starch++ } \\
\text { Stunted } \\
\text { Jan. } 8\end{array}$ & $\begin{array}{c}\text { Plant } \\
\text { Recovered }\end{array}$ \\
\hline & & Vigorous & & & & Normal & Vigorous & $\begin{array}{c}\text { Tall } \\
\text { Vigorous }\end{array}$ & \\
\hline & & & & & & $\begin{array}{c}308 \\
\text { Aug. 22 } \\
309 \\
\text { Sept. } 6\end{array}$ & & & \\
\hline \multirow[t]{4}{*}{ poted } & $\underset{\text { Mar. } 24}{\text { G. }}$ & $\begin{array}{l}\text { Psylla } \\
\text { inoc. } \\
\text { July } 11\end{array}$ & & $\begin{array}{l}\text { C. R. } \\
\text { Jan. } 4\end{array}$ & $\begin{array}{l}\text { G. H. } \\
\text { Apr. 12 }\end{array}$ & & $\begin{array}{l}\text { C. R. } \\
\text { Oct. } 16\end{array}$ & $\begin{array}{l}\text { G. H. } \\
\text { Jan. } 16\end{array}$ & \\
\hline & & & $\begin{array}{l}\text { B. V. } \\
\text { Nov. } \\
16\end{array}$ & $\underset{\text { Jan. } 4}{\text { B. V.- }}$ & $\underset{\text { May } 15}{\text { B. V. }} \underset{\text { starch }+}{+}+$ & & $\underset{\text { Oct. } 16}{\text { B. }}$. ++ & $\begin{array}{c}\text { Not } \\
\text { pruned } \\
\text { Jan. } 16\end{array}$ & $\begin{array}{c}\text { B. V.++ } \\
\text { Apr. } 24\end{array}$ \\
\hline & & & & & $\underset{\text { starch- }}{\text { B. V. - }}$ & & $\begin{array}{c}\text { Vigorous } \\
8^{\prime} \text { tall } \\
(2.4 \text { meters })\end{array}$ & $\begin{array}{l}\text { Pruned to } \\
2^{\prime} \text { high } \\
0.6 \text { meter }\end{array}$ & $\begin{array}{c}\text { See } \\
\text { fig. } 1\end{array}$ \\
\hline & & & & & $\begin{array}{c}300 \\
\text { May 15 } \\
301 \dagger \dagger \\
\text { May } 26\end{array}$ & $\begin{array}{c}303 \\
\text { June } 21 \\
305 \\
\text { July } 25\end{array}$ & & & \\
\hline
\end{tabular}

Date of notes on condition of healthy plants are the same as for diseased.

Leaves were in terminal tufts because internodes of recent growth failed to elongate. Leaves were smaller than normal and d nutritient deficiency symptoms.

Old leaves with severe brown veins on the previous reading abscised.

Tree 2 in this experiment had noninfectious psylla transferred to it.
ingen

See fig. 2 . 
skin) disease of peach, Prunus persica (Schneider, 1945b; Esau, 1958; Nasu, et al., 1970); leaf roll of grapevine (Vitis) (Hoefert and Gifford, 1967); and tristeza (seedling-yellows) disease of seedling of lemons, Citrus limon (L) Burm. f. (Schneider, 1959). It will be disclosed in this paper that pear decline falls into this group. The other group in System 1 would include those phloem diseases in which phloem elements other than the sieve tuhes and companion cells are first affected, with the entire phloem in some instances later becoming involved. For instance, in expanding leaves of curly-top-diseased sugar beets (Beta vulgaris L.) the parenchyma cells adjacent to the first formed sieve tubes hypertrophy (Esau, 1935). Then hyperplasia occurs. Sieve tubes differentiate in the masses of hyperplastic tissue which later becomes necrotic. Other diseases of this group in which the sieve tubes do not become affected but in which hyperplastic and hypertrophic changes occur are the citrus vein-enation virus disease of citrus (Hooper and Schneider, 1969) and the tristeza disease of Mexican lime, (Citrus aurantifolia (Christm.) Swing.) (Schneider, 1959).
System 2 would classify the phloem diseases into three groups on the basis of the developmental stage that the tissue is in when it is first affected. Group one would contain diseases in which only meristematic or semimeristematic tissues are affected, essentially, tissues of the procambial strands in which the first sieve tubes differentiate. In these cases, the causal agent is apparently carried to the procambial cells in the first formed protophloem sieve tubes as with the vein-enation virus disease of citrus (Hooper and Schneider, 1969). Group two would embrace those diseases in which phloem in any developmental stage (primary or secondary) becomes affected. Most of the diseases that affect phloem belong in this group. A third group would be composed of diseases in which the phloem is not affected until the plant body reaches a certain degree of maturity. In the greening disease of sweet orange, metaphloem and secondary phloem are affected after leaves reach maturity (Schneider, 1968). This paper will show that in the particular leaf veins under the present study, only secondary phloem was found to be affected in samples affected by pear decline

\section{MATERIALS AND METHODS}

Tissue samples were collected from 'Variolosa' trees in four inoculation experiments. All trees were grown in the greenhouse and histories of cultural practices and symptom expressions are presented in table 1 . Details of experiments 38 and 54 were previously described (Tsao, Schneider and Kaloostian, 1966). Trees were rooted by Dr. W. H. Griggs from dormant stem cuttings except in experiment 38 where scions were grafted onto Pyrus ussuriensis seedlings. Propagating material was from apparently healthy trees in plots at the University of California, Davis, where pear decline became epiphytotic beginning in 1959 . In the last batch of stem cuttings from this source that were rooted in the fall and winter of 1965-1966, part of the trees exhibited pear decline symptoms. These diseased trees were easily distinguished from healthy ones. We made anatomical studies on one of the diseased trees, but the results are excluded from this report because there was no adequate control tree. In the experiments, trees were psylla-inoculated by George Kaloostian, U. S. Department of Agriculture, Riverside. Pear psylla (Psylla pyricola Foerster) were first caged on trees with pear decline near Danville, California; then they were transferred to 'Variolosa' trees in the greenhouse. 
Noninoculated control trees were included in all experiments, and material from control trees was included in all tissue collections. ${ }^{3}$

Each winter the trees were chilled in a 40-degree Fahrenheit cold room (C.R.) for from two to six months. Trees of some experiments were held in a lath house (L.H.) during early winter until space became available in the cold room. Following transfer of plants to the greenhouse from the cold room in spring, infected trees made a luxuriant flush of growth.

The shoots selected for study were taken from this new growth flush, and the stems were either still elongating or had recently ceased to do so (table 1; figs. 1 and 2). Apical growth of diseased trees ceased sooner than control trees (fig. 2). Records of symptom expression were made at irresular intervals (table 1 ).

In the winter of 1965-1966, trees of experiment 54 were not chilled but kept in the greenhouse throughout the winter. In the spring of 1966 , internodes on the nonchilled infected trees tended to be short; hence the leaves were in tufts (table 1). Sections were not made from this growth. Internodes of control trees were of normal length.

Pieces of tissue that included a main lateral vein were collected from leaves varying in age from the oldest at the bases of shoots to the youngest below stem apices (fig. 2). The stem tips were also collected (fig. 3A). The tissues were killed and fixed for both light and electron microscopy. For the former, Randolph's modified CRAF fluid was used. Tissues were then dehydrated in ethyl-butyl alcohol series, embedded in tissuemat, and sectioned at 6 microns. Sections were stained with Heidenain's hematoxylin and counter-stained with either lacmoid or with safranin and fast green. Iodine-potassium iodide was used to detect starch; and periodic acidSchiff's reagent counter-stained with fast green was used for total carbohydrates of insoluble polysaccharides (Jensen, 1962).

For electron microscopy, the material was carried through the following steps: fixed for one hour in cold 3 per cent glutaraldehyde huffered in $\mathrm{pH} 7.0$ phosphate buffer; washed in cold phosphate buffer; post-fixed for three to five hours in 1 per cent phosphate buffered osmium tetraoxide in an ice bath; rinsed in distilled water; dehydrated in a graded series of ethyl alcohol; treated with propylene oxide; and embedded in Maraglas. Sections were cut with a glass knife on a Porter-Blum MT 2 ultramicrotome and stained with uranyl acetate and lead citrate. Relatively thick sections varying from 0.2 to 0.25 microns were also cut from the same block and stained with toluidine blue for monitoring. Observations of ultra-thin sections were made with a RCA EMU 3B electron microscope.

\section{OBSERVATIONS}

\section{Histogenesis of the leaf}

To determine the stage of rein de. velopment at which pathological aberrations began to appear in newly forming shoots on chronically diseased plants, a comparison was made between the lateral vein development of infected and healthy plants at irregular inter- vals following dormancy chilling (table 1 ). Veins of leaves that were in stages of development varying from leaf primordia with early marginal growth to mature leaves were studied. Differences in vein development between the diseased and healthy leaves were not detected until the beginning of differen-

\footnotetext{
${ }^{3}$ An abbreviated form is used forthwith to identify specimens. For instance, tissue collection number 301 from control tree number 28 in experiment 72 will be designated healthy $72: 28$ (301).
} 


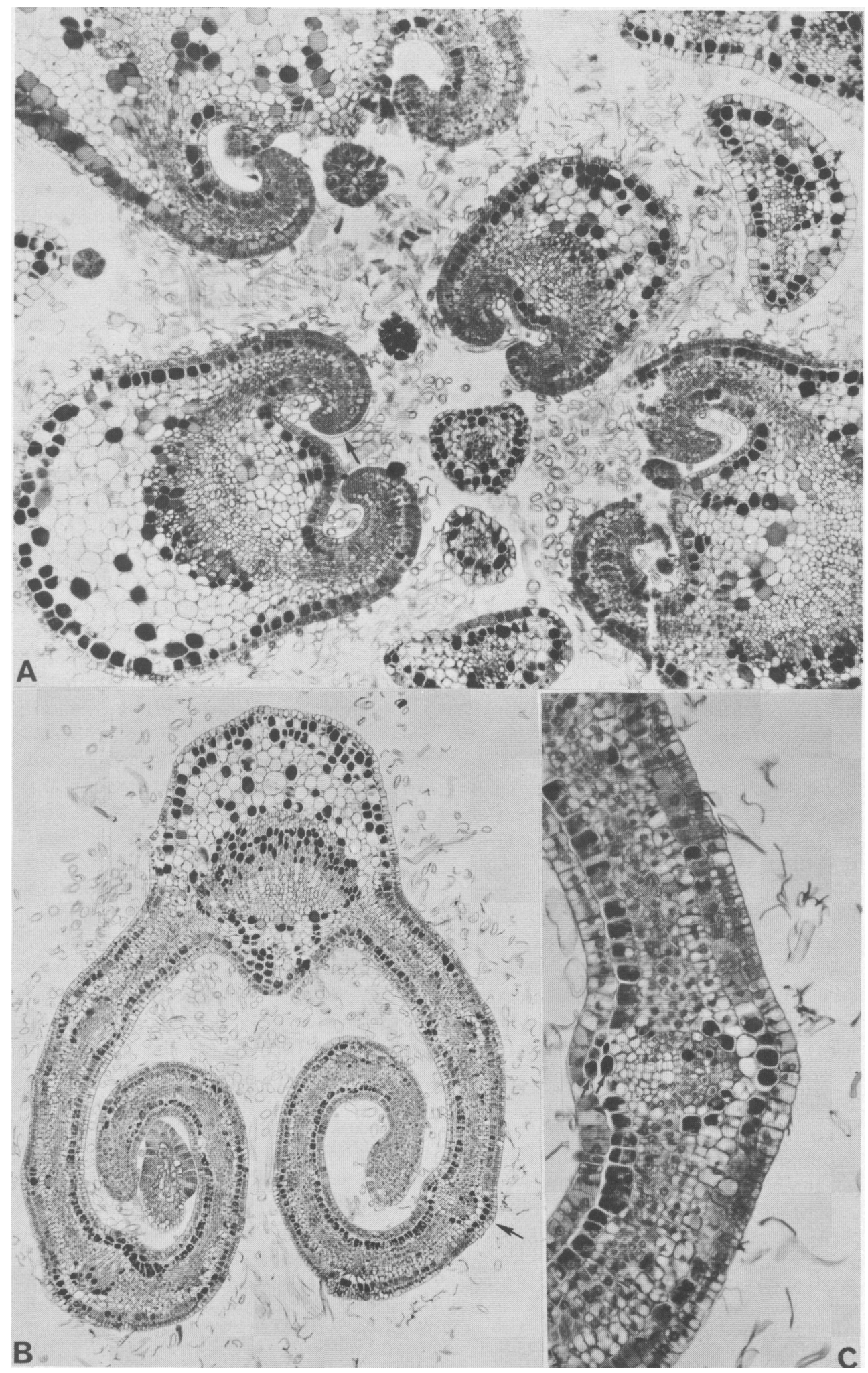


tiation of the secondary vascular tissue. However, the marginal growth, the formation of procambial strands, and the differentiation of vascular tissue are briefly described as a basis for understanding the anatomy of veins and for future studies of leaves affected by other diseases that may show structural aberrations in the primary body.

Marginal growth of the lamina. Marginal growth consisted of divisions of the marginal and the submarginal initials of the marginal meristem (figs. 3 and 4). No single marginal initial cell in cross sections could be identified, but a few cells at the leaf margin which may be referred to as the marginal initials divided actively in anticlinal planes giving rise to the adaxial and abaxial protodermal layers. The daughter cells of course continued to divide as the leaf expanded and they ultimately differentiated into adaxial and abaxial epidermi (fig. 4). The formation of the internal tissues of the lamina was traced to the activity of a strand of longitudinally arranged submarginal initials which appeared in cross section as a single cell (fig. 4). Each initial cell divided alternately in periclinal and anticlinal planes (fig. 4A and B). The anticlinal divisions gave rise to the adaxial and abaxial subprotodermal layers (fig. 4B). The periclinal divisions supplied cells to the inner part of the lamina which we call the middle mesophyll layers (fig. 4A and B). The cells of adaxial subprotodermal layer divided anticlinally except at the site of veins, so as to perpetuate themselves as an independent layer in the young lamina. On the other hand, periclinal divisions were observed in the abaxial derivative cells, which contributed cells also to the middle layer (fig. $4 \mathrm{~A}$ and C). Therefore, a layered cell arrangement in the abaxial subprotoderm was not clear in the region close to the submarginal initial. Then, it became a distinct layer at varying distance from the submarginal initials by anticlinal divisions of constituent cells.

As soon as both abaxial and adaxial subprotodermal layers were established, tannin was formed in them causing them to be prominent in the young lamina (fig. $3 \mathrm{~A}, \mathrm{~B}$, and $\mathrm{C}$ ). In the adaxial subprotodermal layer, tannin was sometimes observed in cells closer to the submarginal initial than in the abaxial subprotodermal layer.

Usually the young lamina consisted of the adaxial and abaxial protodermi, the subprotodermi, and the middle mesophyll layers, which consisted of three to four tiers of cells (fig. 3C and $4 \mathrm{C})$. The mature lamina had the following mesophyll organization: a pallisade tissue consisting of two tiers of elongated cells, one of which derived from the adaxial subprotodermal layer and the other from the uppermost cells of the middle mesophyll layers; and a spongy tissue derived both from the middle mesophyll layers and from the abaxial subprodermal layer.

\section{Differentiation of the lateral veins.} The origin of the lateral veins first became apparent with the differentiation of procambial strands from ground meristem in the middle mesophyll near the submarginal initials (fig. 4A). Cells giving rise to the procambiums were in the portion of middle mesophyll layers adjacent to the adaxial subpro-

Fig. 3. Photomicrographs of cross sections of newly forming leaves on an elongating shoot. A. Sections of leaf primordia above the apical meristem of healthy 28:72(300), 33 days after chilling dormancy (table 1). Laminae are forming on primordia; one of the marginal meristems (arrow) is more highly magnified in figure 4A. B. Section of leaf 17, which was $13 \mathrm{~mm}$ long, from a shoot of healthy $38: 1$ (302) 22 days after dormancy chilling. See figures $3 \mathrm{C}$ and $6 \mathrm{~B}$ for higher magnification of the vein indicated by the arrow. C. Higher magnification of one of the main lateral veins in figure $3 B$. Note the recently divided cells in the adaxial subprotodermal layers (arrows). They contribute to the bundle sheath extension. $(\mathbf{A}, \times 120 ; \mathbf{B}, \times 80 ; \mathbf{C}, \times 260$.) 


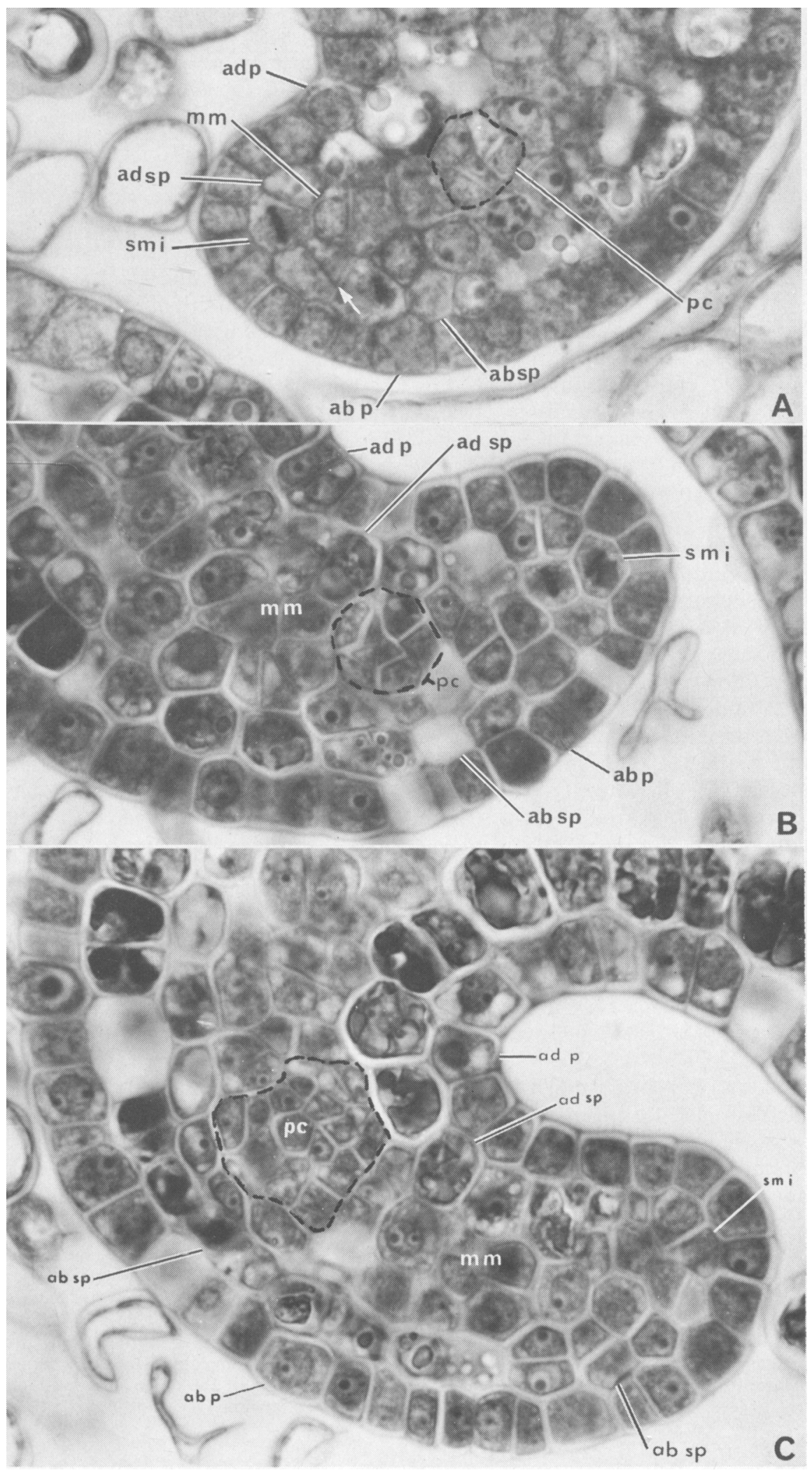


todermal layer. The layer of middle mesophyll cells adjacent to the abaxial subprotoderm did not seem to contribute to the procambium (fig. 4). The developing procambial strand increased further in diameter by cell divisions within it (fig. $4 \mathrm{~B}$ and $\mathrm{C}$ ). Later, the cells in the adaxial subprotodermal layer divided several times by periclinal walls, thus forming several layers of cells between the procambium and adaxial protoderm (fig. 3C). They differentiated into the adaxial bundle sheath extension (fig. 9A) which caused a slight elevation of the adaxial surface of the lamina along the major lateral veins. The cells of the abaxial subprotodermal layer as well as the one-cell layer of the middle mesophyll layers, apparently did not divide so frequently, but they enlarged conspicuously forming the abaxial bundle sheath extension, which caused a slight elevation of the abaxial surface (fig. 3C).

The bundle sheath formed from the ground meristem cells around the procambial strand. Its cells were larger than those of the strand, and were sometimes filled with dense, homogenously staining substance, presumably tannin, which became granular and yellowish as seen in fixed and stained sections of the mature leaf (fig. 9A).

As the procambial strand reached some thickness, its cells were arranged in tiers, and the first protophloem sieve tube differentiated on the abaxial side (figs. 5 and 6A). The sieve tube was distinguishable from neighboring cells, because of its smaller size, different kind of stainable contents, and a rela- tively thick cell wall (figs. 5 and 6A). Several protophloem sieve tubes of similar structure differentiated subsequently in the protophloem (figs. 6B and $\mathrm{C}$ ). This was preceded by random cell divisions which destroyed the arrangement of cells into tiers. Nacreous walls of the protophloem sieve tubes were thinner than those of the metaphloem sieve tubes (compare figs. 5 and $7 \mathrm{C}$ ).

Sieve tubes in the metaphloem had thick, nacreous walls; their shapes were somewhat irregular, and they were randomly arranged (fig. 7A, C, and D). Companion cells, if present, could not be distinguished from parenchyma cells. Formation of the nacreous walls in the developing sieve elements occurred before such maturation changes as nuclear and tonoplast degeneration (fig. 7B). After the walls became thickened, part of the organelles, the nucleus and the tonoplast disappeared, and sieve-tube starch and amorphous bodies appeared. The sieve plates usually were located in oblique end walls of the sieve element and occasionally in transverse end walls (fig. 7D).

The first xylem elements began to differentiate on the adaxial side of the procambial strand, while the first sieve tube was maturing (fig. 5). Some rows of cells that radiated from the adaxial side became larger and more vacuolated than cells in other rows, but the tiered arrangement was not destroyed as in the phloem. The enlarged cells differentiated into tracheary elements with thickened lignified walls (figs. 5 and $6 \mathrm{~B}$ to $\mathrm{D})$. Cells in rows adjacent to

Fig. 4. Photomicrographs of cross sections of developing healthy leaves showing marginal meristems and differentiating procambial strands of lateral veins. A. Periclinal division of the submarginal initial $(s m i)$ and a very early stage of procambial $(p c)$ differentiation. The cell contiguous to the submarginal initial has recently divided periclinally (arrow). See figure 3A for lower magnification. B. Submarginal initial $(s m i)$ in anaphase of mitosis; division is in an anticlinal plane. Periclinal division in metaphase is shown in the immediate derivative cells of the submarginal initial of the middle mesophyll $(\mathrm{mm})$. Further development of the procambium $(p c)$ is also shown. C. Cells of the abaxial subprotodermal layer ( $a b s p$ ) near the submarginal initial have divided by periclinal walls supplying their daughter cells to the middle mesophyll. A later stage of procambium ( $p c)$ development is shown. (All $\times 1200$.) (B and $\mathrm{C}$ from infected tree $38: 2(302$.) In these and all following figures abbreviations are: $s m i$, submarginal initial; $a d p$ and $a b p$, adaxial and abaxial protoderm; $a d s p$ and $a b s p$, adaxial and abaxial subprotodermal layers; $m m$, middle mesophyll; $p$, procambium. 
tracheary elements were smaller, and some became filled with tannin. Maturation of the xylem elements radiated from the protoxylem toward the phloem.

Differentiation of secondary tissues. After the metaxylem cells were initiated, and while they were differentiatin $r$, divisions of cells between the xylem and phloem became restricted to a sheet of cells that gave rise to radially narrow phloem mother cells (fig. 6D). This shift from randomly occurring divisions to divisions in one plane constituted the initiation of the cambium and the beginning of the secondary tissue formation.

The cambial layer gave rise to some phloem mother cells, which either divided to form sieve-tube elements and companion cells or differentiated into a parenchyma cell. Other phloem mother cells divided in a radial plane resulting in two daughter cells. The daughter cells either divided again by a radial or oblique wall to form a sieve tube element and a companion cell, or the cell differentiated into a parenchyma cell (figs. 8A and $\mathrm{C}$ and fig. 13A). This secondary phloem was distinguishable from primary phloem, because it was more or less in tiers.

The development of nacreous walls in the secondary phloem seemed to take place simultaneously in many sievetube elements, and the walls became so thick that only a narrow lumen remained. The thickness of the wall was not homogenous. In the thinner part of the wall, fibrils were densely packed into layers, while in the thicker part fibrils were irregularly. arranged and loosely packed (figs. 8B and 13B). The narrow lumen was irregularly shaped; a tonoplast was not evident, and the protoplast contained sieve-tube starch, amorphous bodies, mitochondria, dictyosomes and endoplasmic reticula (fig. 8B).
Sieve-tube members and their associated companion cells were often easily recognized because of their common origin from a sieve-tube mother cell and the nature of their subsequent differentiation. The companion cells were shorter than their associated sieve-tube members and therefore not present in all cross sections of sieve tubes. In spite of the common origin of the sieve-tube member and its companion cell, it was not always possible to distinguish companion cells from parenchyma cells. Companion cells were filled with cytoplasm containing many small vacuoles, whereas the vacuoles of parenchyma cells were often coalesced into a large central one. The ground cytoplasm of companion cells contained endoplasmic reticulum, and large numbers of mitochondria (fig. 13B). The endoplasmic reticulum was sometimes massive as shown in a diseased specimen (fig. 12).

Scattered tannin-containing parenchyma cells occurred just outside the secondary phloem in the metaphloem (fig. 9B). By the time secondary phloem began to form, a lysis of sievetube contents had occurred in all of the protophloem and the older metaphloem, and there was some collapse and obliteration of the walls (figs. 7C and 9B). At the same time the primary phloem fiber walls became thickened.

Ray cells in the secondary phloem, like the axial tissue, were formed by cambial cells usually in continuity with those of the xylem (fig. 8A).

It was not determined how much secondary xylem was formed. Usually tracheary elements located contiguous to the cambium were of smaller diameter than those of the earlier formed xylem and their abaxial tangential walls were of approximately the same thickness as those of the adjacent cambial cells. These smaller tracheary elements may be secondary (figs. $8 \mathrm{~A}, 9 \mathrm{~A}$, and 10B). 


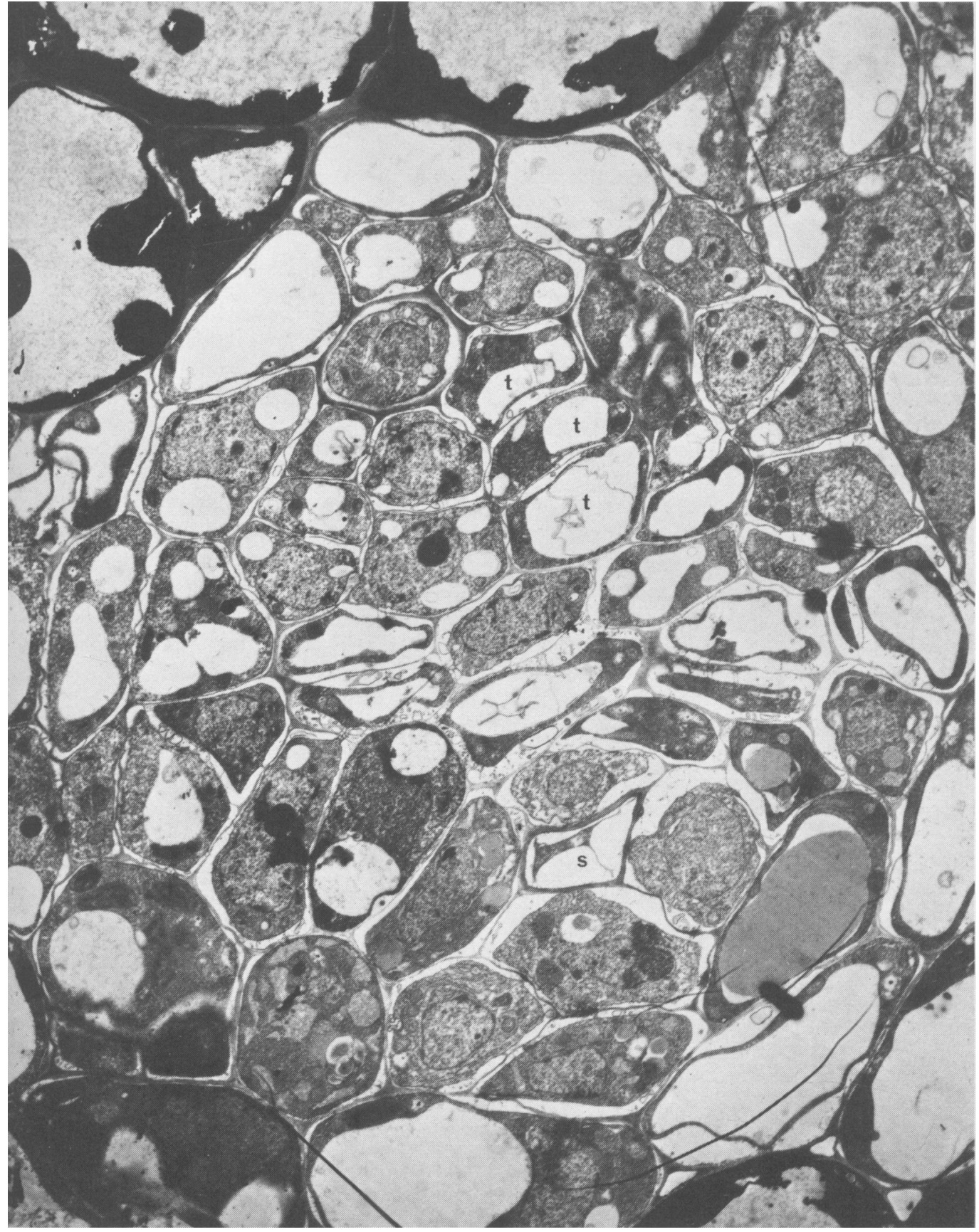

Fig. 5. Electron micrograph of a cross section of a lateral vein procambium with early stages of phloem and xylem differentiation. From a developing leaf $1 \mathrm{~cm}$ long near the shoot apex of infected but symptomless 38:2(302). The first sieve tube $(s)$ has differentiated in the protophloem. Note its thickened walls. Tracheary elements $(t)$ are differentiating. Development is apparently normal. $(\times 48,400$.) 


\section{Pathological aberrations in the structure of lateral veins of diseased leaves}

Differences between diseased and healthy tissue were not observed until after secondary growth was initiated. The first abnormality observed in our samples was accumulation of starch. This however could have been a response to a basipetally located hlock. age of translocation. The first structural change was necrosis of the sieve tubes and companion cells (fig. 10). Organelles and ground cytoplasm in the companion cells became disorganized, and the protoplasts appeared to be structureless and shrunken from their walls. At the same time sieve-tube walls collapsed slightly, the lumens became constricted and the protoplasm lost its granular nature and became homogeneous (figs. 10A and 11). In phloem that had thick-walled sieve tubes present at the onset of structural aberrations, destruction of these important elements was all that we observed. The overall structure of phloem produced subsequent to the onset of symptoms was more drastically affected.

One of the most obvious effects of pear-decline disease on veins that followed the onset of necrosis was hyperactivity of the cambium and the production of excessive abnormal phloem in the lateral veins (fig. 9C and D). In the lateral vein of the healthy plants, the cambium produced only a limited amount of secondary phloem and then ceased activity (fig. 9A and B). In diseased plants, after formation of what should have been the total compliment of sieve-tube elements, the cambial cells continued dividing by tangential walls to give rise to phloem mother cells. In our limited observations, these mother cells did not divide by radial divisions to form two rows of cells as sometimes occurred in healthy plants (compare figs. 8A and 10B). The mother cells either divided by tangential or oblique walls to form the cells from which a sieve-tube element and companion cell differentiated, or they differentiated directly into parenchyma cells. Since the phloem mother cells acted as sieve-tube mother cells directly without first dividing to form two narrow rows of cells, and since these sieve-tube mother cells divided in tangential planes to form sieve-tube elements and companion cells rather than in radial planes as in healthy leaves, the sieve-tube elements and companion cells were in some instances somewhat wider tangentially than those of healthy plants (compare figs. $10 \mathrm{~B}$ and $8 \mathrm{C}$ ). Some of them were radially narrow, and the nacreous walls of the sieve-tube elements were thinner than normal. The middle lamella of radial walls was abnormally thickened as if by hydration (fig. 10B). The sieve tubes at first contained organelles and granular amorphous substances as do normal sieve tubes, but they soon became necrotic and collapsed.

Most of the parenchyma cells that formed by hyperactivity of the cambium seemed to be normal (fig. 10B); and after most of the abnormal sieve tubes and companion cells collapsed, the parenchyma cells together with tannin containing ray cells became the major component of the phloem (fig. 9D). Each phloem parenchyma cell contained a large, elongated nucleus, many mitochondria, and plastids with starch grains. Later some of these parenchyma cells underwent hypertrophy and occasionally hyperplasia.

As leaves became older, the cambium continued to be hyperactive, producing far more phloem than the healthy plant. The degree of phloem formation however was not homogeneous throughout. Parts of the cambium produced small amounts of either normal or abnormal secondary xylem rather than phloem so that the cambial sheet became undulated rather than smooth. Cambial cells had thickened cyctoplasm (fig. 9D). Abnormally large amounts of starch oc- 


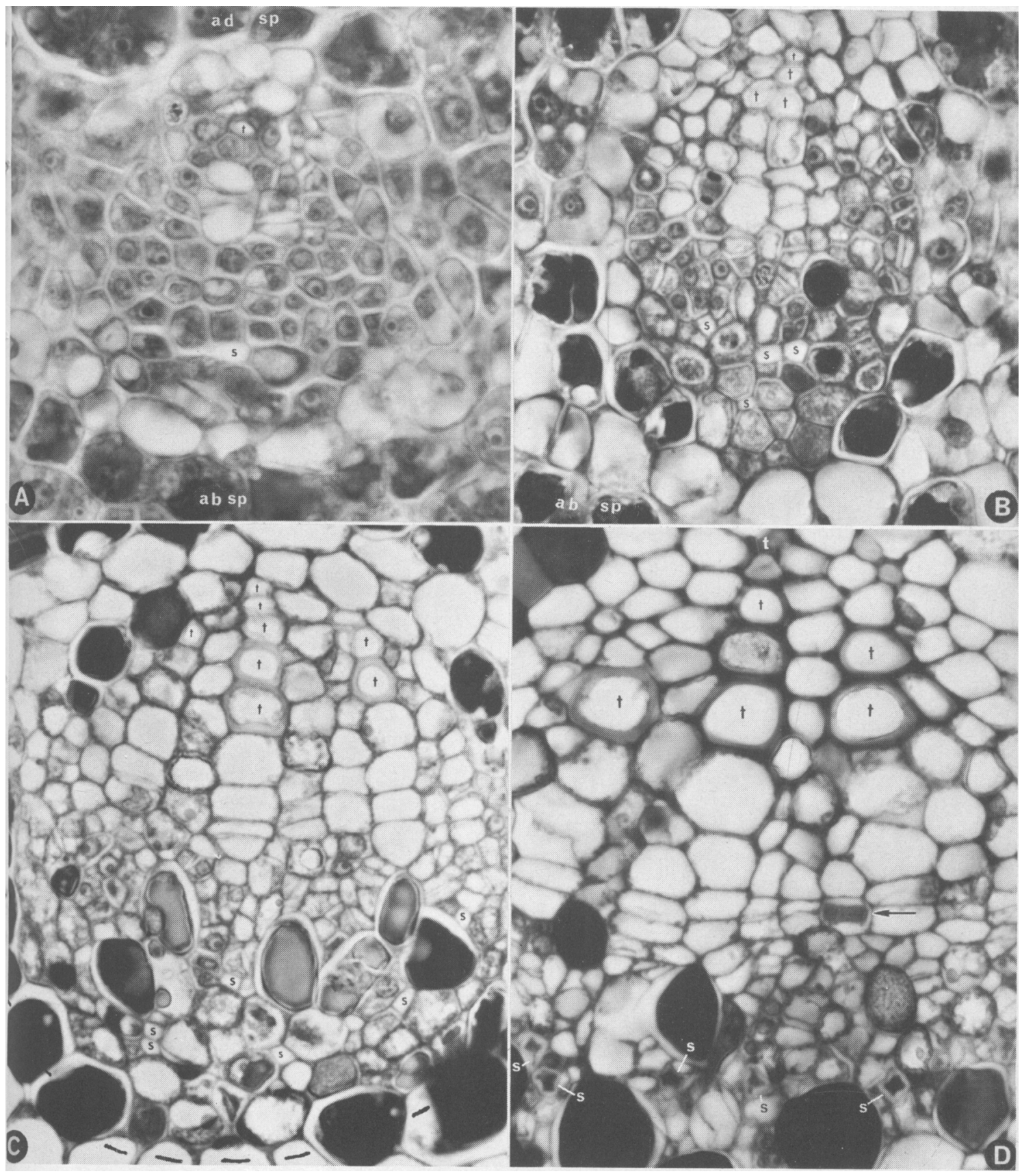

Fig. 6 Photomicrographs of cross sections of lateral veins showing successive stages of vein development in healthy plants. A, B, and C. Plant 38:1(302). Leaves that had not unrolled. $\mathbf{A}$. One of the older primordia in the stem apex. B. A leaf $13 \mathrm{~mm}$ long just below the stem apex. C. A leaf $20 \mathrm{~mm}$ long, three leaves below the apex. D. Plant $72: 28(300)$. A half-unrolled leaf $40 \mathrm{~mm}$ long. The adaxial side of the leaf is at the top in each figure.

A. The first protophloem sieve tube $(s)$ and protoxylem trachery element $(t)$ have differentiated. B. Several sieve tubes $(s)$ and lignified xylem elements $(t)$ are mature. Note the cell division in the immature xylem (left of large immature tracheid). C. Further stage of vein development. The radially narrow cell in the center of the border between phloem and xylem presum. ably shows the initiation of cambial activity. Broken line indicates the bundle sheath. D. Still further stage of vein development in which the cambial layer has been established. Note a cell division in the cambium (arrow). Several sieve tubes $(s)$ have nacreous walls. $(\mathbf{A}, \times 990 ; \mathbf{B}$. C, D, $\times 940$.) Adaxial subprotodermal layer $(a d s p)$; abaxial subprotodermal layer $(a b s p)$. 


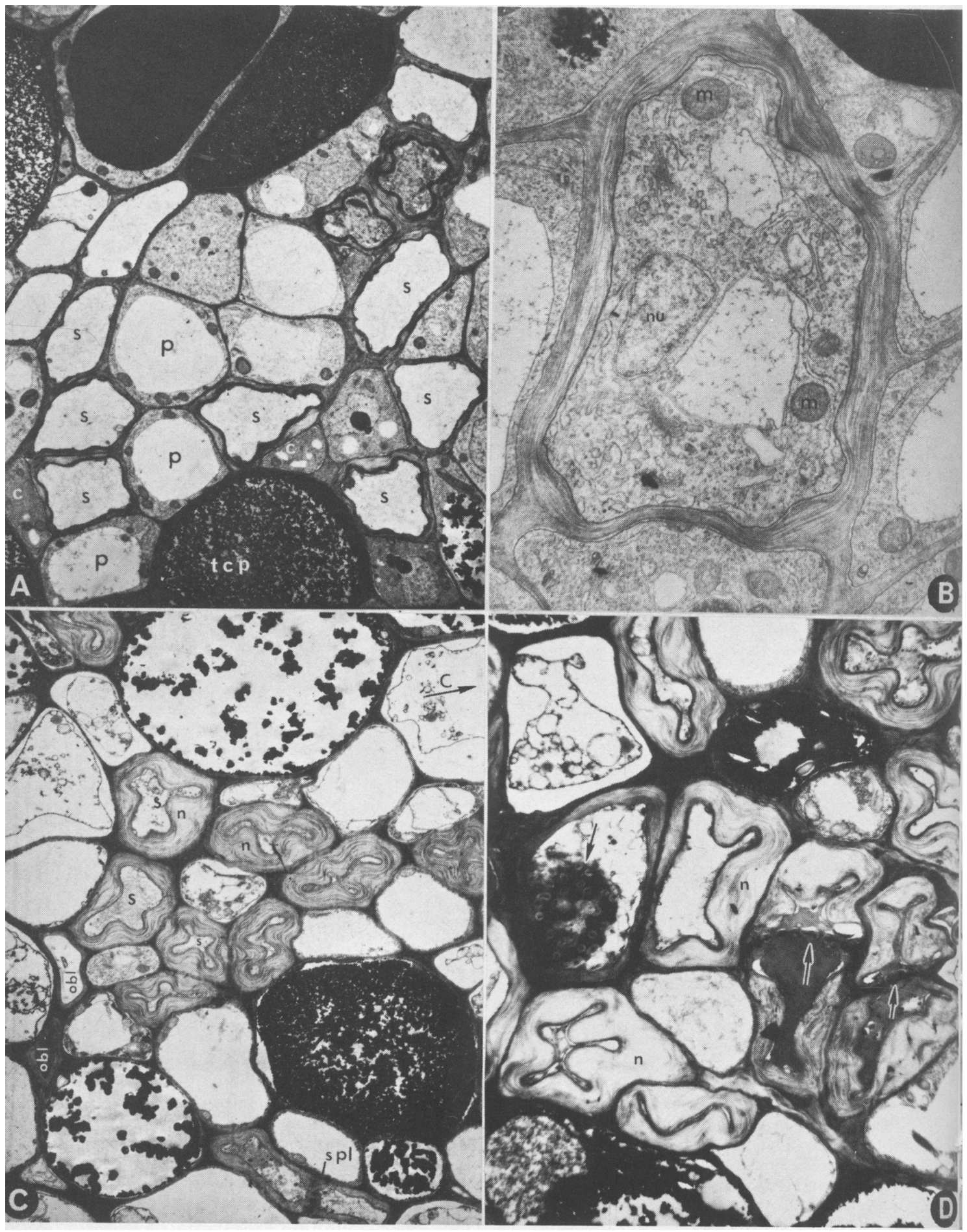


curred in parenchyma cells of the rays, phloem, bundle sheath, sheath extensions, and the mesophyll cells (fig. 9C). There was conspicuous hypertrophy of some parenchyma cells in the bundle sheath extensions and of parenchyma cells interspersed in protophloem fiber bundles.

\section{Cytology of pathological sieve tubes} and companion cells. The necrosis of companion cells and sieve tubes involved a general deterioration of the ground cytoplasm, the endoplasmic reticulum, and organelles (figs. 11 to 16); membranes became fuzzy, and a structureless mass remained that contained ribosome-like structures. The structures were short, imperfectly shaped rods that became more conspicuous as the cytoplasm deteriorated (compare figs. 13 and 14 with 15 and $16)$.

Since completing the research reported herein, Hibino and Schneider (1970) reported that mycoplasma-like bodies occur in the sieve tubes of pear decline-diseased trees. Upon reviewing our electron micrographs, we found similar mycoplasma-like structures in diseased phloem, some of which had been labeled "peculiar bodies" (fig. 17). Not recognizing their possible importance in causing sieve-tube necrosis at that time, we did not search further for them.

\section{DISCUSSION}

\section{Marginal growth of the lamina}

Although many workers of leaf histogenesis have assumed the existence of a single strand of marginal initials which presumably gives rise to the protoderm, some did not recognize them (Cross, 1937, 1938; MacDaniels and Cowert, 1944; Maksymowych and Erickson, 1960). In the present study of expanding leaves, it was not possible to distinguish a single strand of marginal initial cells. On the contrary, dividing cells were observed all through the margin of the lamina, as well as throughout the laminar surface.

Three kinds of ontogeny in the formation of the middle layer have been described: (1) directly from the submarginal initial by periclinal divisions (Avery, 1933), (2) from the abaxial subprotodermal layer (Foster, 1935), and (3) from the adaxial subprotodermal layer (Gifford, 1951). However, more than one of these patterns may occur in leaves of the same plant and even in one leaf (Cross, 1937, 1938; Gifford, 1951; Girolami, 1954; Pray, 1955; Hara, 1957). Cross (1937, 1938) observed in Viburnum that the middle mesophyll is formed both from the submarginal initial and from the abaxial subprotodermal layer. Hara (1958) observed this type of formation in some species of Ericaceae and their allies and called it "abaxial-middle" type. This pattern of formation of the middle layer was observed in pear leaves in the present study with periclinal divisions in cells of the abaxial subprotodermal layer at times contributing cells to the

Fig. 7. Metaphloem of lateral veins. Electron micrographs of cross sections. A and $\mathbf{B}$ are portions of the metaphloem of a developing major lateral vein of a leaf that had unrolled except at its margins in healthy $54: 2(306)$. A. Note several sieve tubes $(s)$ with thin, nacreous walls, companion cells $(c)$, and large tannin containing parenchyma cells $(t c p) .(\times 3,870)$ B. Metaphloem sieve tube element in early stages of differentiation. Several small vacuoles and a nucleus $(n u)$, mitochondria $(m)$ and other cytoplasmic organelles are still present. Note that nacreous wall with layered structure $(\times 14,800)$. C. and D. Later-formed portion of the metaphloem from fully expanded leaves of healthy $72: 28(301)$ C. Fully expanded leaf 4 shown in figure 2. Sieve tubes $(s)$ have thick, nacreous walls $(n)$. A sieve plate $(s p l)$ is present in cross-sectional view. Two sieve tubes are being obliterated $(o b l)$. Cambium lies in the direction shown by arrow $c$ $(\times 3,900)$. D. From fully expanded leaf 10 (see fig. 2 ). Note the sieve plate in face view (black arrow) and others in cross sectional view (black on white arrows). $n=$ nacreous walls. $(\times 5,250$.) 


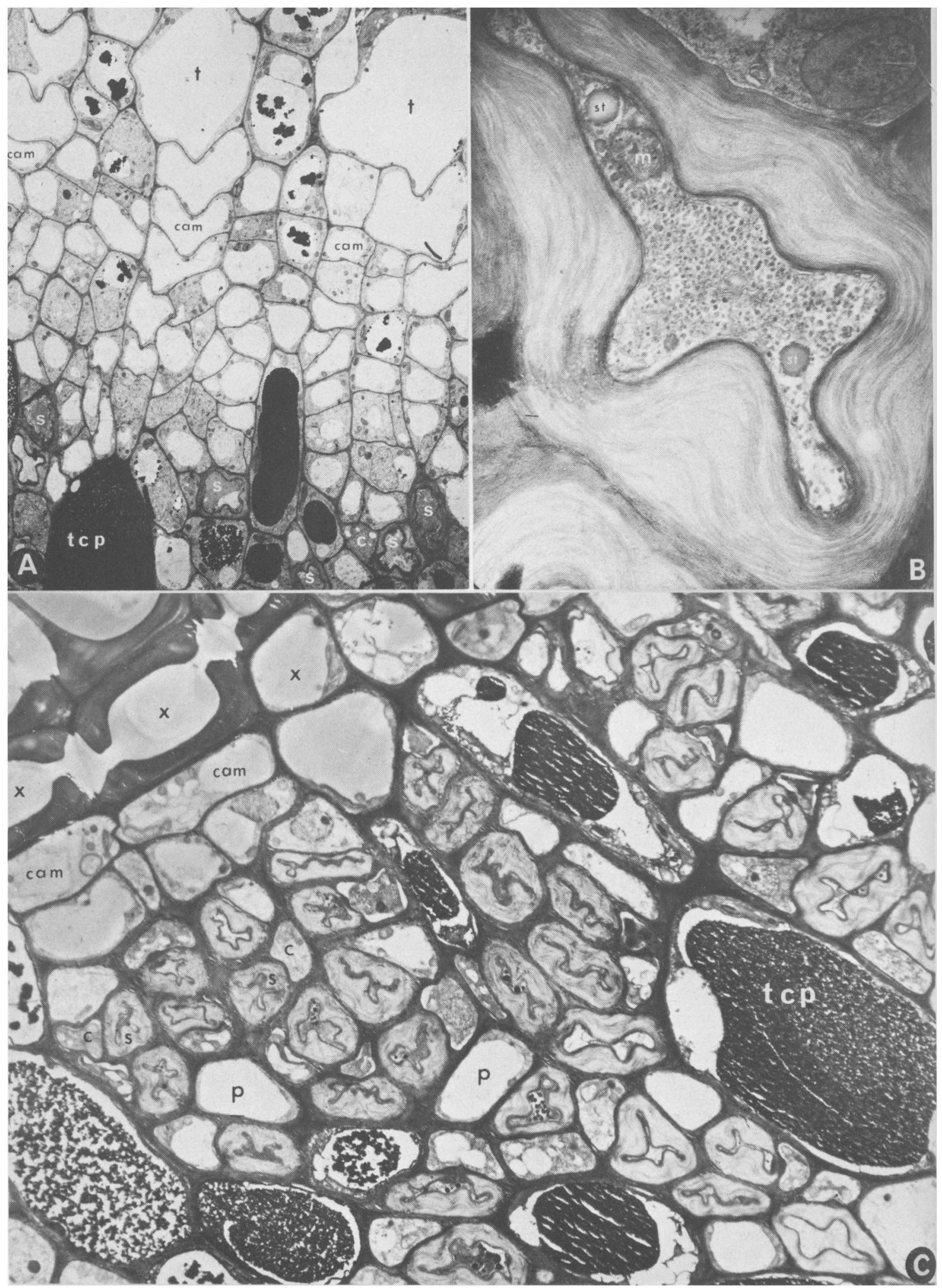


middle layer. Sometimes these divisions occurred in the cell next to the submarginal initial. The middle layer became several cell-layers thick. Cells of the abaxial subprotodermal layer divided only by anticlinal walls and was there.. fore a distinct layer.

The young lamina of the pear, like typical dicotyledonous leaves, was fairly stratified. It consisted of adaxial and abaxial protoderms and subprotoderms and three to four cell-layers in the middle of the leaf except in the regions of procambium. The mature leaf had a palisade layer consisting of two tiers of elongate cells, one of which derived from the adaxial subprotodermal layer and the other from the uppermost cells of the middle layer. Schneider (1952) called this two-source origin of the multiseriate palisade layers "heterogeneous" as distinguished from "homogeneous" palisade layers which arise only from the derivatives of the adaxial subprotodermal layer. The spongy layers in Variolosa are derived in part from the middle layer and in part from the abaxial subprotodermal layer.

\section{Differentiation of the lateral veins}

The procambia that give rise to the veins of the dicotyledonous plants differentiate exclusively in the middle layers (Esau, 1965), and those of larger veins are multiseriate from their inception (Pray, 1955; Girolami, 1954). In the present study the procambians of major lateral veins were derived from a few cells of the middle layers adjacent to the adaxial subprotoderm. Sub- sequent cell divisions in various planes increased the thickness of the developing procambial strand.

Early formation of the protophloem was represented by a sieve tube which differentiated at the abaxial side of the procambium. The sieve tube could be distinguished from parenchyma cells because of its thicker walls and thin protoplast.

Nacreous walls of sieve tubes of the lateral veins were prominent in Variolosa. Schneider (1945a) described nacreous walls in peach and cherry, and Esau and Cheadle (1958) found them in 45 of 142 plants examined. In the present study, wall thickening was especially remarkable in sieve tubes of the secondary phloem. The nacreous walls showed a crenulated inner margin which made the shape of the lumen of the sieve tube irregular in cross section. Electron micrographs clearly showed a layered structure in the walls. That the nacreous part of the wall is a true secondary wall has not been demonstrated for any plant (Esau, 1965). The walls of the protophloem sieve tubes of pear were nacreous in early stages of differentiation. In well-developed nacreous walls of secondary phloem sieve tubes, there was no boundary which delimited them from the primary wall. These facts may suggest the primary nature of the nacreous wall.

Some workers described the formation and the activity of the cambium in leaf veins (Esau, 1934; Bond, 1942; Schneider, 1945a; Shtromberg, 1959).

Fig. 8. Secondary phloem of lateral veins. Electron micrographs of cross sections. A. Lateral vein in an early stage of secondary growth, from a leaf that was nearly unrolled and $45 \mathrm{~mm}$ long from healthy 54:2(306). Tiers of cells derived from the cambium will differentiate into secondary phloem. Early stages of tannin accumulation occur in the vacuoles of some of the recently formed ray cells. Metaphloem sieve tubes $(s)$; tannin containing parenchyma cells $(t c p)$; partially differentiated tracheary element $(t) ;(\times 2060$. $)$ B. Cross section of an apparently normal sieve tube of the secondary phloem of a mature leaf from infected 72:27(305) mitochondrion $(m)$; sieve-tube starch $(s t)$. Dictyosomes and endoplasmic reticulum are also present. $(\times 18,300$. $)$ C. Cross section of a portion of the mature secondary phloem from healthy 54:2(311). Sieve tubes $(s)$ and associated companion cells $(c)$ are somewhat regularly arranged forming tiers that radiate from cambial cells $(\mathrm{cam})$. Tannin containing parenchyma cells $(t c p)$; lignified xylem element $(x)$; parencyma cell $(p) .(\times 3,600$. $)$ 
According to them, the cambial layer appears at an early stage of differentiation. Sieve-tube arrangement in the primary phloem of lateral veins of pear leaves was rather irregular, and frequently sieve tubes were not associated with companion cells. However, sieve tubes of the secondary phloem were arranged in regular rows with companion cells. Some secondary xylem formation was observed. It also occurs in some evergreen trees (Shtromberg, 1959).

\section{Pathological developments in the lateral veins}

Sieve-tube necrosis in the lateral veins was absent until after differentiation of the secondary phloem commenced. This absence in primary phloem may have been because new growth following dormancy chilling was likely, at first, pathogen free. The first visible, structural aberrations found in some phloem diseases of plants occur at the level at which the first primary sieve tubes differentiate (Esau, 1935, 1941; Schneider, 1945b; Girolami, 1955), and this has been evidence that the causal agents move through sieve tubes as soon as they become functional. The effects produced by these pathogens are either sieve-tube necrosis-or hypertrophy, hyperplasia, and necrosis of parenchyma cells. The latter may be accompanied by over-production of sieve tubes.

Esau (1956) suggested the possibility of dividing the phloem diseases into groups according to their characteristic primary symptoms. In the review of literature, we suggested two ways of doing this. One way was on the basis of the kind of elements first affected. Pear decline belongs in the sieve-tube necrosis group along with potato leaf roll, buckskin disease of peach, leaf roll of grape vine, and tristeza disease of seedling lemons.

The deterioration of companion cells in diseased 'Variolosa' leaves was different from the necrosis of cells in various plants and animals that were induced by various physical forces (Wrischer, $1965)$. In the latter, there was a formation of vesicles from dictyosomes and mictochondria. In other words, the changes were physical as were the forces that induced them. On the other hand in pear decline-diseased companion cells, structures seemed to "dissolve."

We first thought that the ribosomelike materials that remain in deteriorated companion cells might be virions, but the mycoplasma-like bodies reported by Hibino and Schneider (1970) now seem more probably the causal agent of pear decline. 


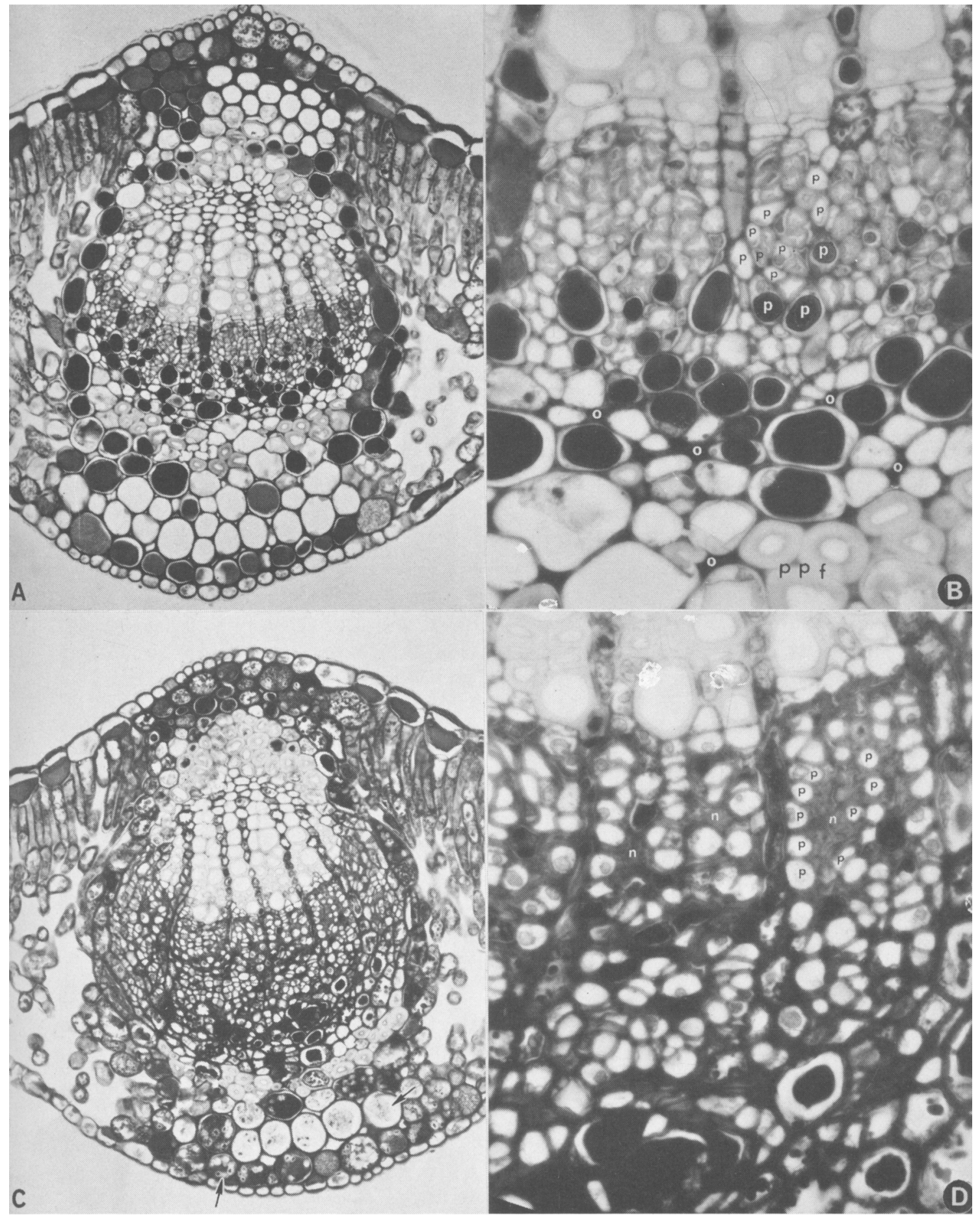

Fig. 9. Photomicrographs of cross sections of lateral veins of mature leaves from healthy $54: 2(311)$ and diseased 54:1(311). A. Healthy vein. B. Higher magnification of part of the phloem in $\mathbf{A}$. Sieve tubes and companion cells are interspersed amongst parenchyma cells $(p)$. The sieve tubes have thick, crenulated nacreous walls that nearly fill the lumens. Obliterated sieve tubes $(o)$ occur in the nonfunctional primary phloem. C. and D. Vein from a diseased leaf. $\mathbf{D}$ is a higher magnification of a portion of the phloem in $\mathbf{C}$. Sieve tubes and companion cells are necrotic $(n)$, collapsed, and interspersed among parenchyma cells $(p)$. Starch is accumulating in the bundle sheath extensions (arrows in $\mathbf{C})$. ( $\mathbf{A}$ and $\mathbf{C}, \times 200 ; \mathbf{B}$ and $\mathbf{D}, \times 795$.) 


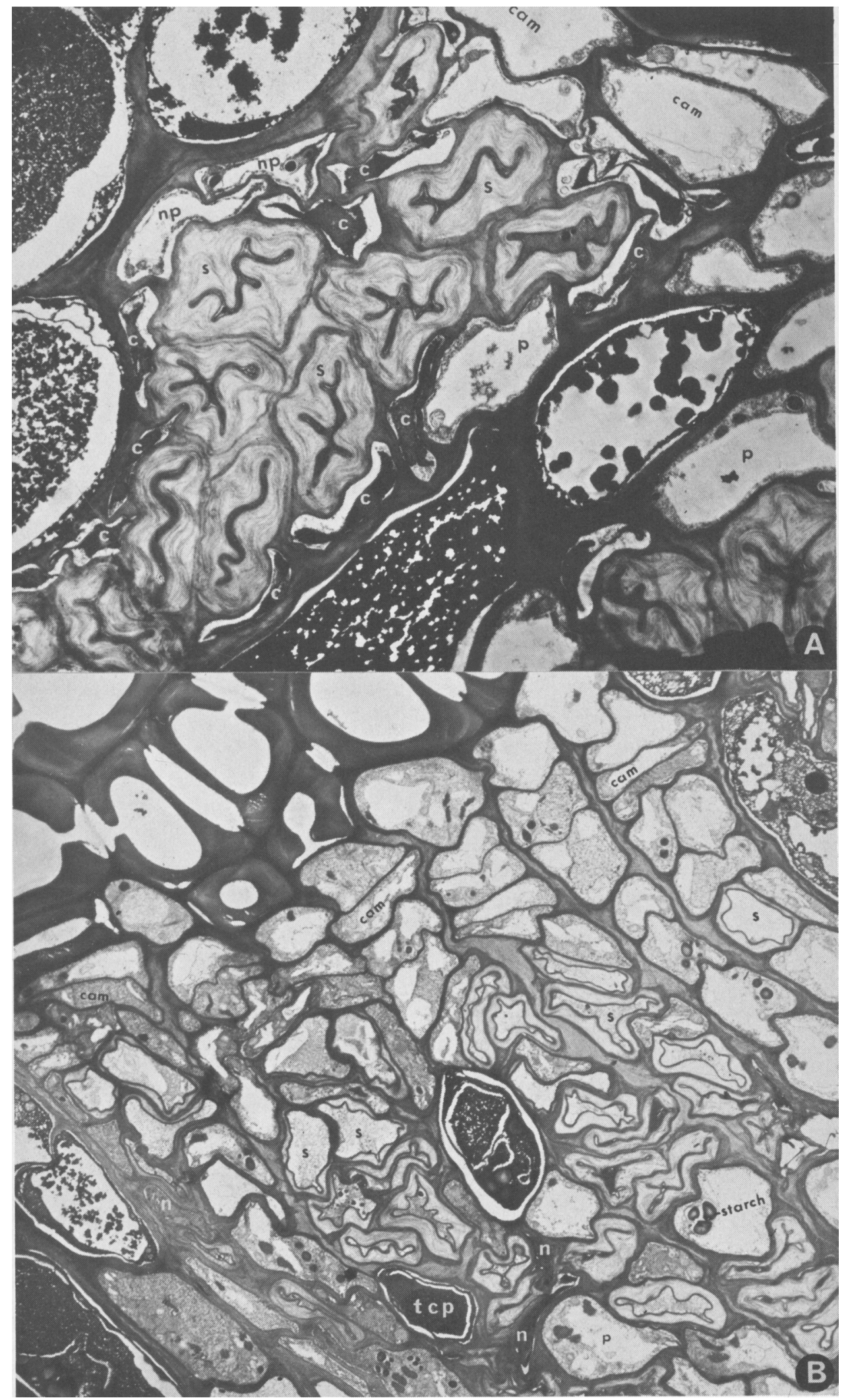


Fig. 10. Electron micrographs of diseased secondary phloem. A. Onset of necrosis in secondary phloem. The organelles and cytoplasm in companion cells (c) have become structureless masses, and sieve-tube walls $(s)$ have collapsed slightly and closed the lumens. Some parenchyma cells $(p)$ are normal while others are necrotic $(n p)$. The leaf was mature from the first growth flush on a stem that was resuming growth on infected $38: 2(304)$. B. Hyperactive formation of abnormal secondary phloem in a chronically affected vein of a mature leaf on $72: 27(305)$. Sieve tubes $(s)$ are abnormally large; their nacreous walls are thinner than in healthy trees, and they may soon become necrotic $(n)$. In some phloem areas, the middle lamella is greatly expanded. $(\mathbf{A}, \times 5,500 ; \mathbf{B}, \times 3,600$. $)$ 


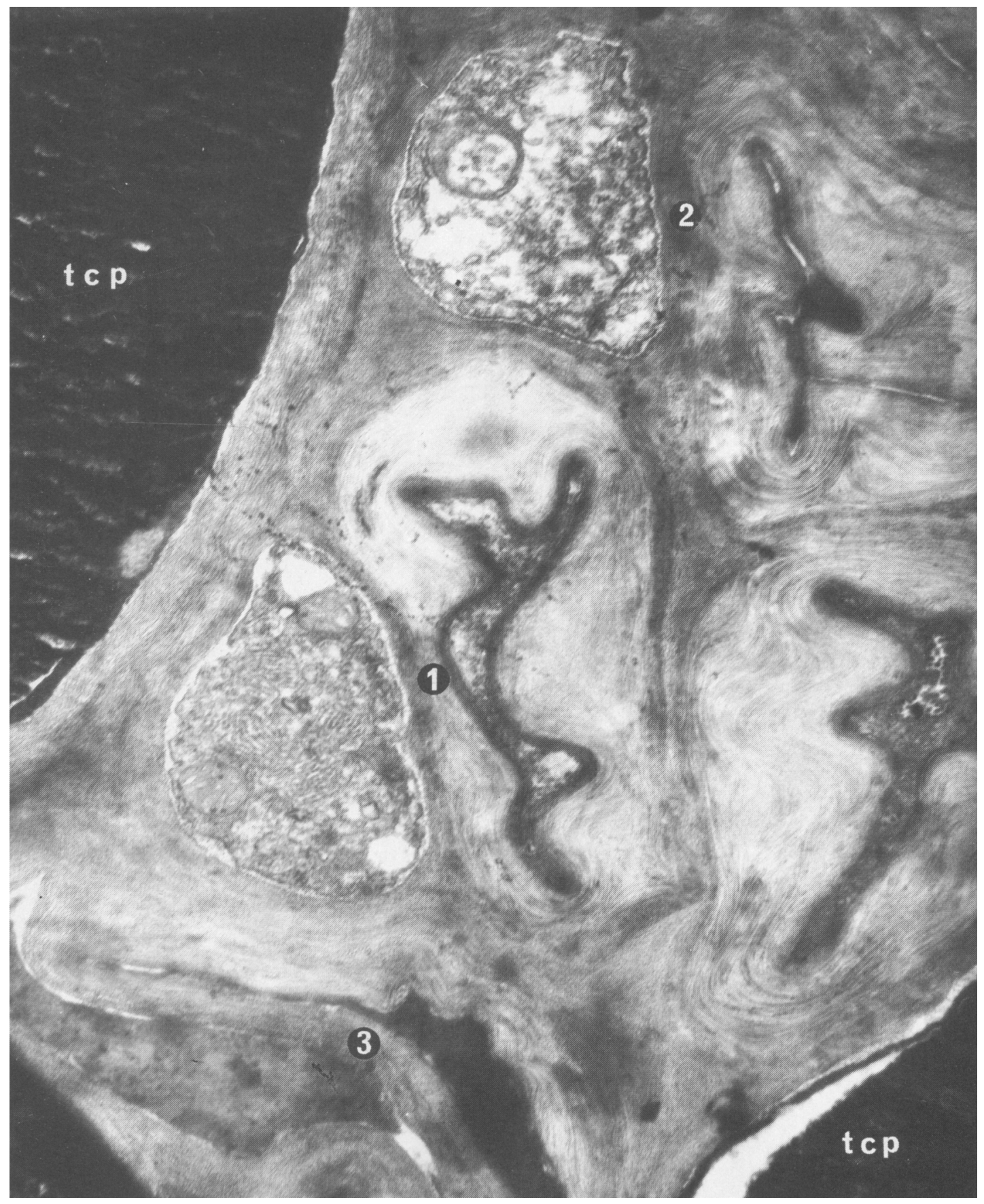

Fig. 11. Electron micrographs of three stages of degeneration of sieve-tube member and associated companion cell units in the secondary phloem of a lateral vein of a mature leaf from infected $72: 27(305)$. The sieve tube-companion cell unit, numbered 1, may be in an early stage of degeneration. There is a mass of endoplasmic reticulum in the companion cell. (See fig. 12 for greater magnification.) The ground cytoplasm and organelles of the companion cell of unit 2 are breaking down; the sieve-tube element has partially collapsed and its granular contents have become a structureless mass. In unit 3, the sieve-tube member and companion cell have collapsed, and their protoplasts have become structureless masses, except that in the companion cell some ribosome-like structures remain. Tannin containing parenchyma cell $(t c p) .(\times 20,000$.) 


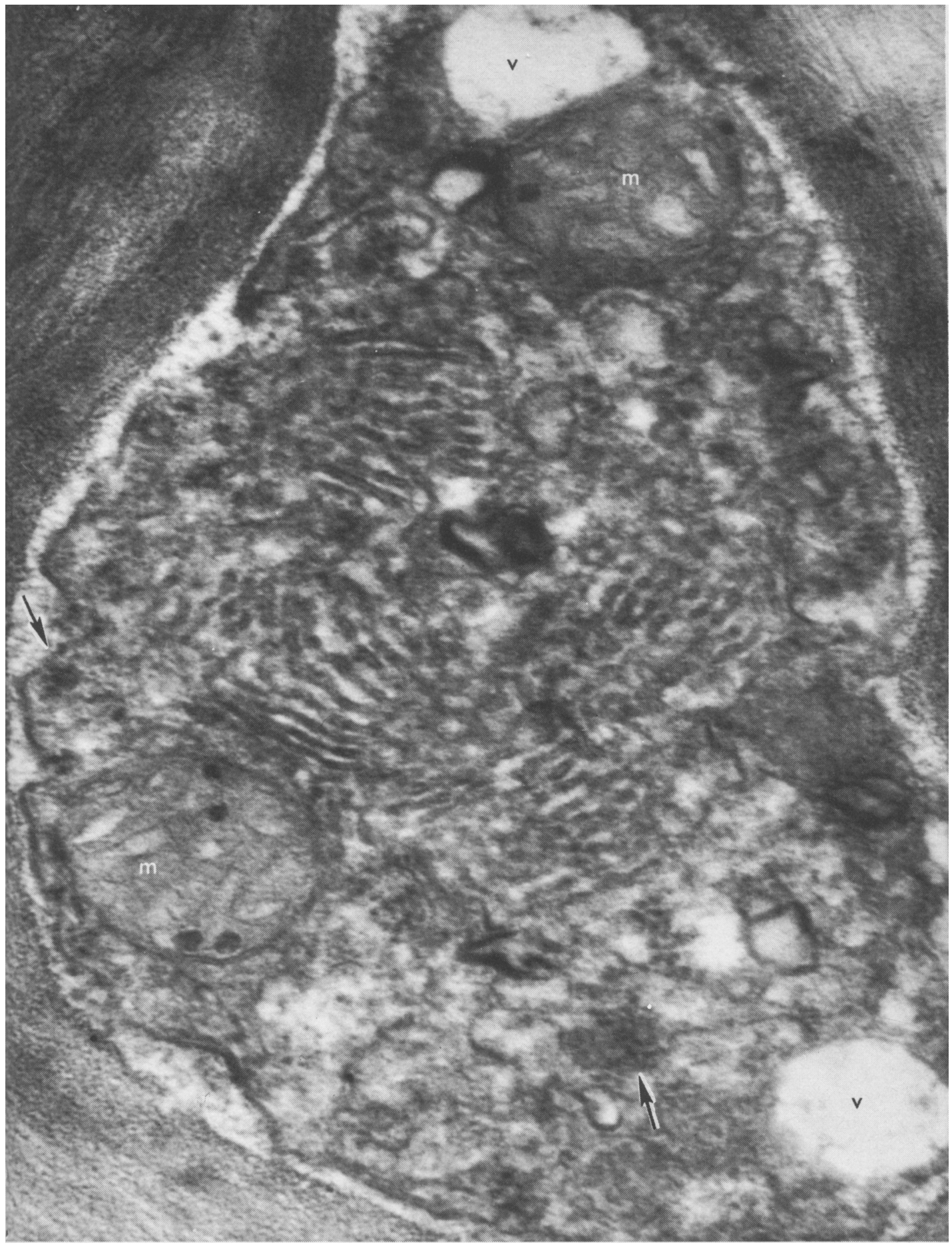

Fig. 12. Higher magnification of the companion cell of unit 1 in figure 11. There is a large mass of endoplasmic reticulum, mitochondria $(m)$, vacuoles $(v)$, and masses of ribosomes (arrows). $(\times 72,000$. 


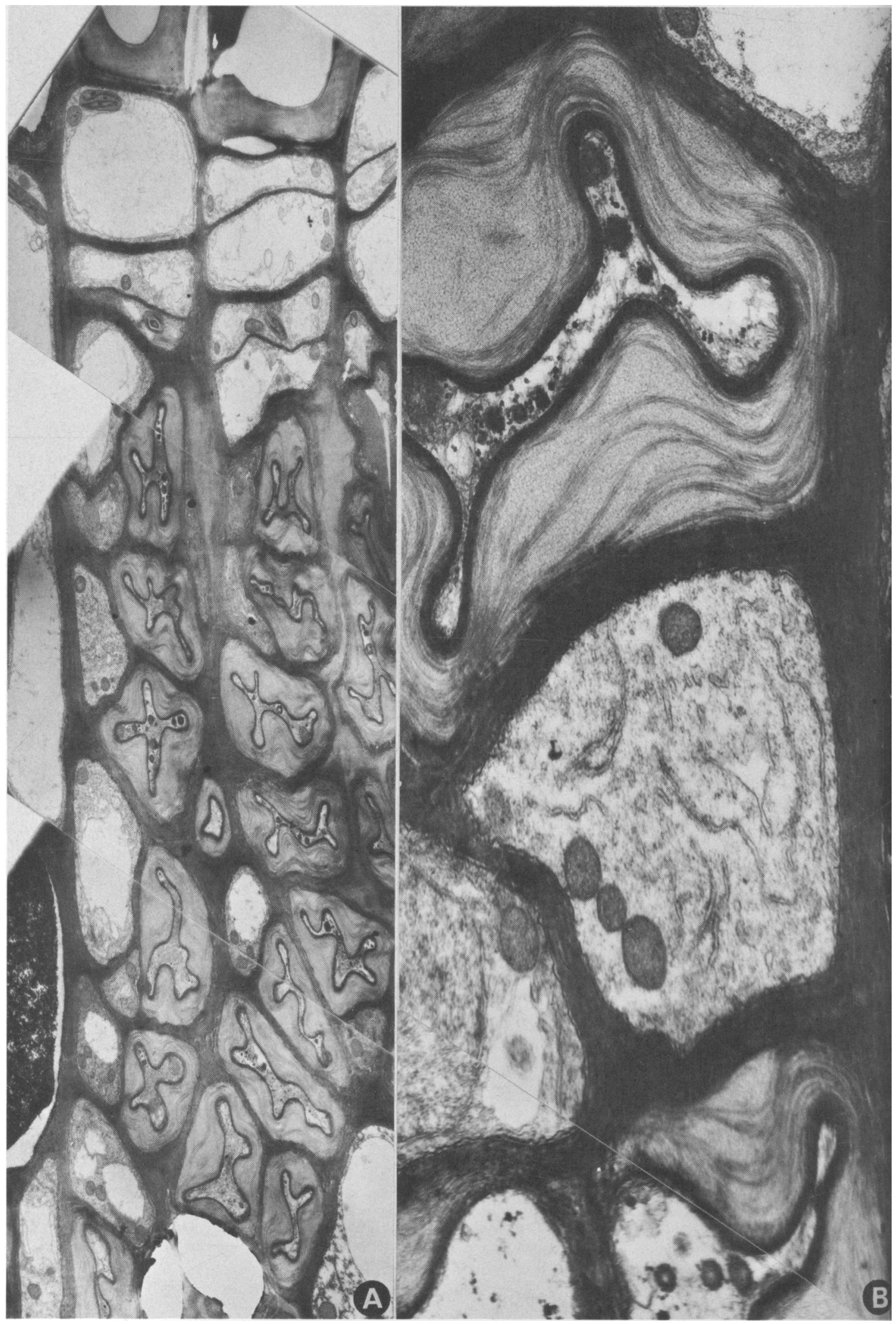

Fig. 13. Secondary phloem of a lateral vein, from healthy $72: 28(305)$. A. Sieve-tube bearing tissue with xylem and cambium at top of picture. $(\times 4,900$.) B. Sieve-tube with nacreous walls above and presumed companion cell just below. $(\times 18,000$.) 


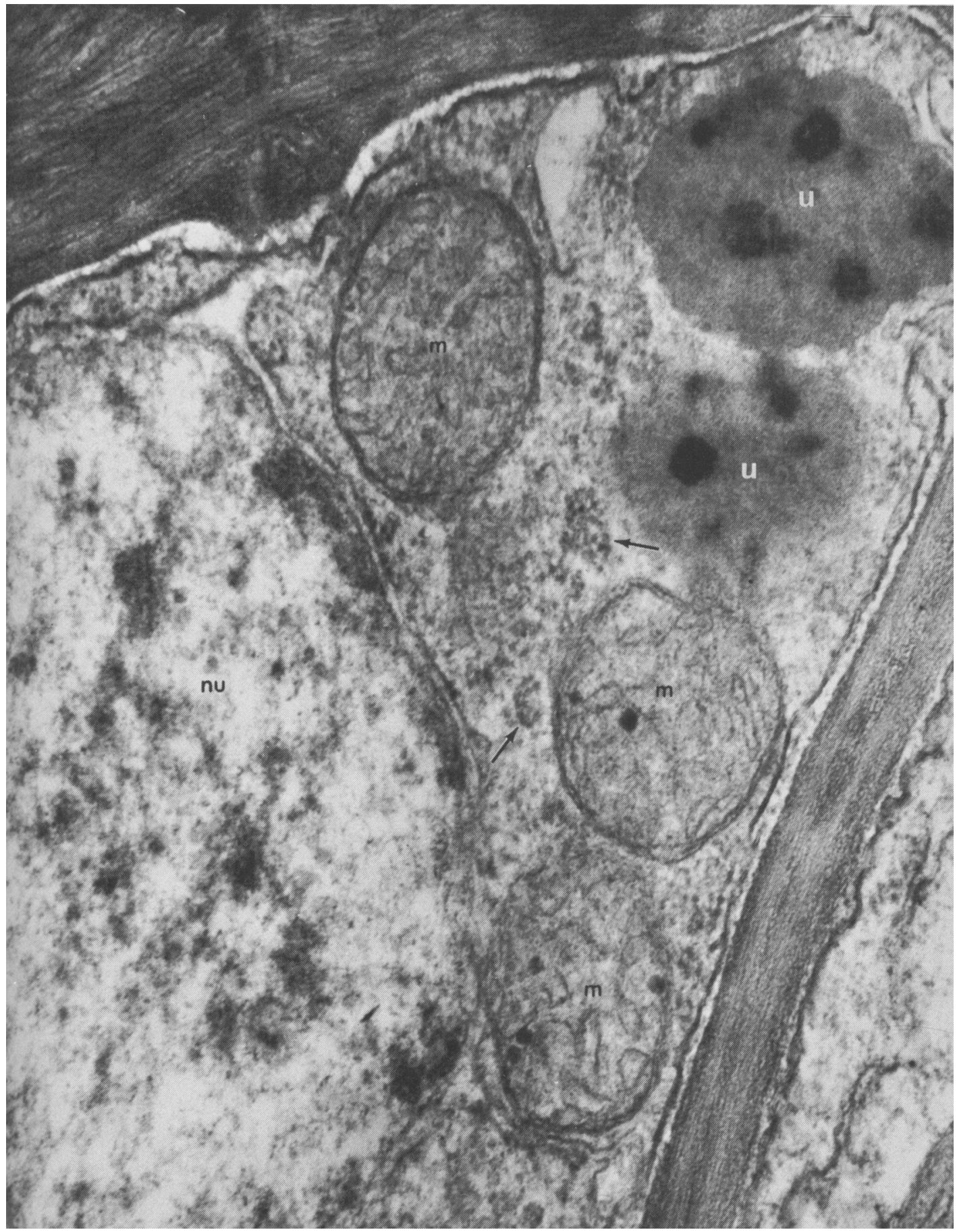

Fig. 14. Portion of a companion cell from healthy $72: 28(305)$. Nucleus $(n u)$; mitochondria $(m)$; unknown bodies $(u)$. Arrows point to ribosomes. $\times 74,000$. 


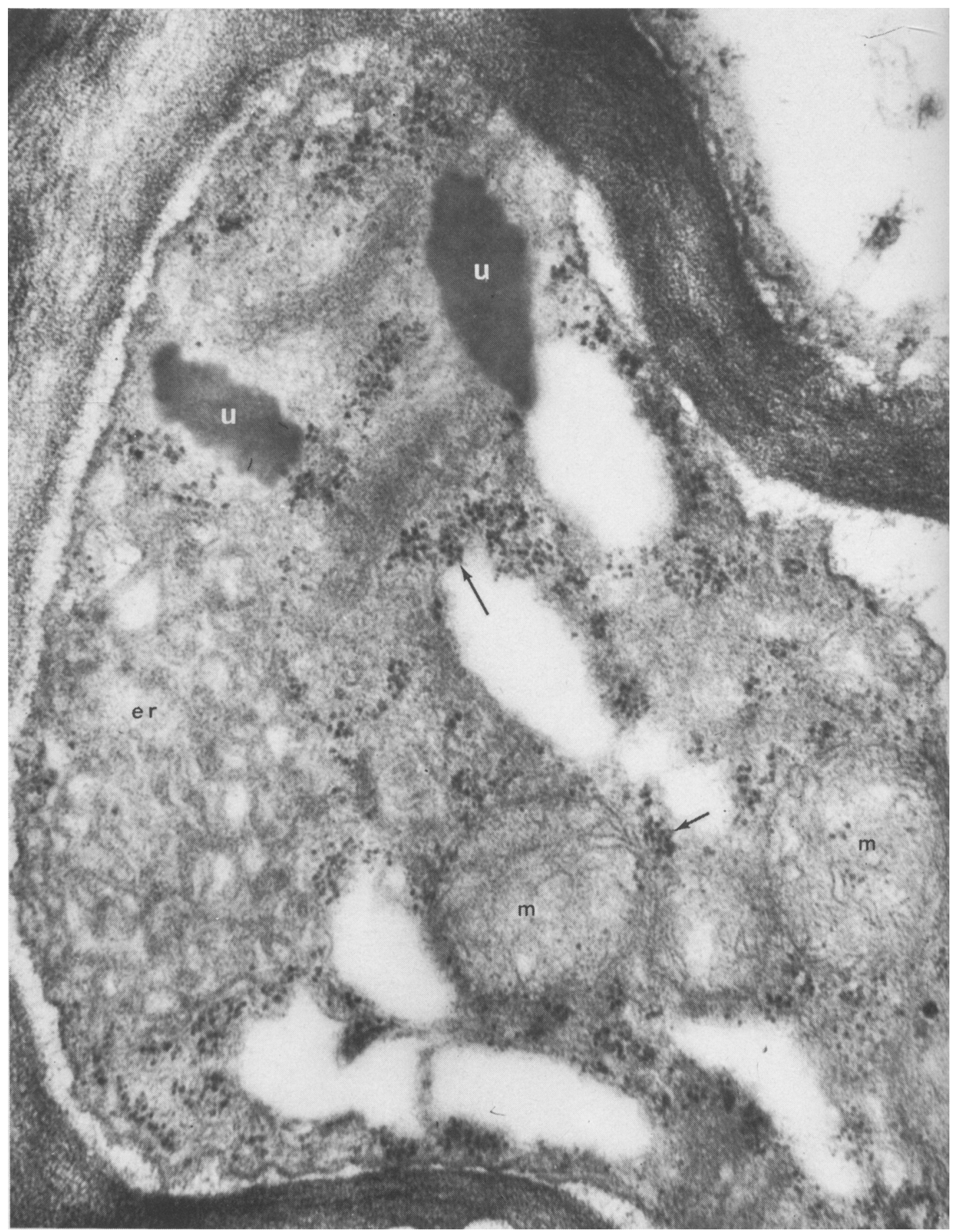

Fig. 15. Companion cell from a major lateral vein of infected $72: 27(305)$ in a stage of degeneration at which the mass of endoplasmic reticulum $(e r)$, ground cytoplasm, and mitochondria $(m)$ are breaking down. Unknown bodies $(u)$ have degenerated. Ribosome-like structures (arrows) are stained relatively dark. $(\times 59,000$.) 


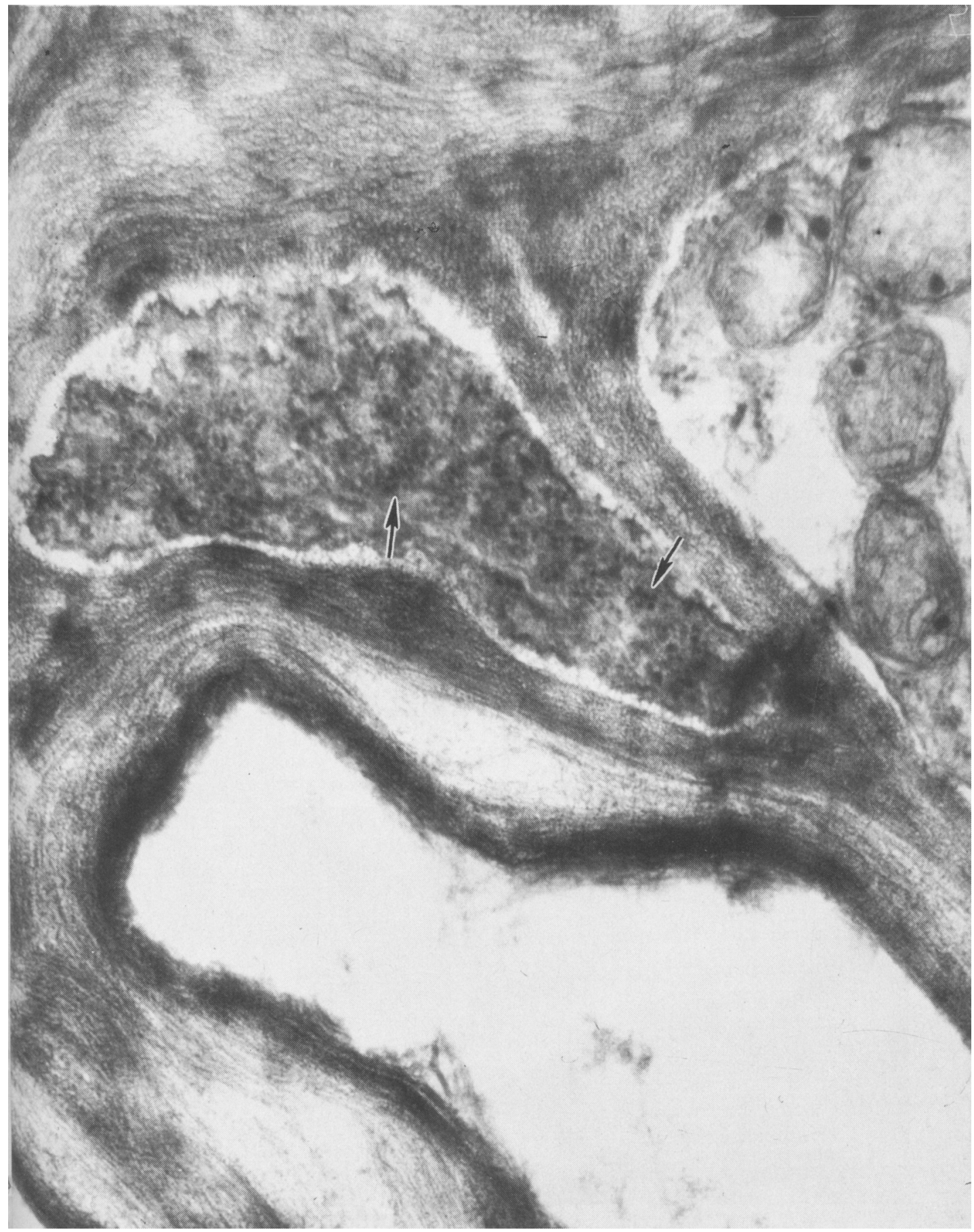

Fig. 16. Severely deteriorated companion cell and sieve tubes of a leaf vein of infected $72: 27(305)$. All of the organelles have deteriorated in the companion cell, except that some ribosome-like structures remain (arrows). Sieve tube is void of organelles. $(\times 62,000$. 

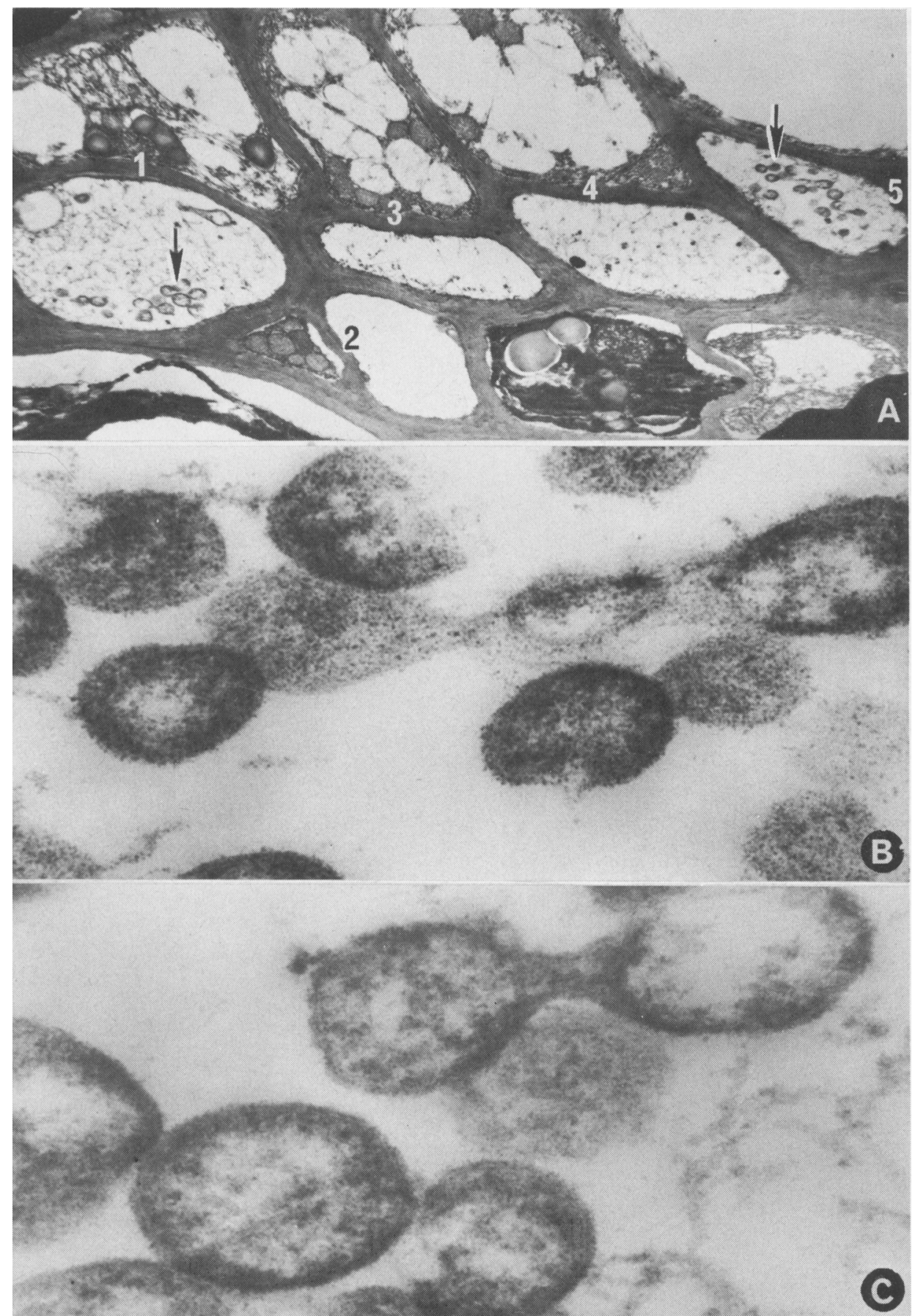

Fig. 17. Mycoplasma-like bodies in sieve-tube elements of a major lateral vein of infected $54: 1(311)$. A. Five sieve tubes with their associated companion cells are indicated by the arabic numerals 1 to 5 at the common wall (whether a companion cell for sieve tube 5 occurs at the level of the section is not clear). Arrows point to some of the mycoplasma-like bodies in the sieve tube elements. $\mathbf{B}$ and $\mathbf{C}$, higher magnification of mycoplasma-like bodies. $(\mathbf{A}, \times 34,000 ; \mathbf{B}$ and $\mathbf{C}$, $\times 93,600$.) 


\section{LITERATURE CITED}

Avery, G. S., JR.

1933. Structure and development of the tobacco leaf. Amer. Jour. Bot. 20:565-92.

BoND, T. E. T.

1942. Studies in the vegetative growth and anatomy of the tea plant (Camellia thea Link.) Cross, G. L. with special reference to the phloem. I. The flush shoot. Ann. Bot. N. S. 6:607-30.

1937. The morphology of the bud and the development of the leaves of Viburnum rufidulum. Amer. Jour. Bot. 24:266-76.

1938. A comparative histogenetic study of the bud scales and foliage leaves of Viburnum opulus. Amer. Jour. Bot. 25:246-58.

Duloy, Margaret, F. V. MERcer, and N. RATHgeber

1961. Studies in translocation. II. Submicroscopic anatomy of the phloem. Australian Jour. Biol. Sci. 14:506-18.

EsAU, KATHERINE

1934. Ontogeny of phloem in the sugar beet (Beta vulgaris L.). Amer. Jour. Bot. 21:632-44.

1935. Ontogeny of the phloem in sugar beets affected by the curly-top disease. Amer. Jour. Bot. 22:149-63.

1939. Development and structure of the phloem tissue. Bot. Rev. 5:373-432.

1941. Phloem anatomy of tobacco affected with curly top and mosaic. Hilgardia 13:437-90.

1956. An anatomist's view of virus diseases. Amer. Jour. Bot. 43:739-48.

1958. Phloem degeneration in celery infected with yellow leaf roll virus of peach. Virology 6:348-56.

1965. Plant anatomy. 2nd Ed. J. Wiley \& Sons, Inc. N.Y. London, Sydney. 767 pp.

1967. Minor veins in beta leaves: structure related to function. Proc. Amer. Phil. Soc. 111:219-33.

Esau, Katherine, and V. I. Cheadle

1958. Wall thickening in sieve elements. Natl. Acad. Sci. Proc. 44:546-53.

Esau, Katherine, V. I. Cheadle, and E. B. Risley

1962. Development of sieve-plate pores. Bot. Gaz. 123:233-43.

Esau, Katherine, and J. Cronshaw

1967. Tubular components in cells of healthy and tobacco mosaic virus-infected Nicotiana. Virology 33:26-35.

Esau, Katherine, J. Cronshaw, and L. L. Hoefert

1967. Relation of beet yellow virus to the phloem and to movement in the sieve tube. Jour. Cell Biol. 32:71-87.

Foster, A. S.

1935. A histogenetic study of foliar determination in Carya buckleyi var. arkansana. Amer. Jour. Bot. 22:88-147.

1936. Leaf differentiation in angiosperms. Bot. Rev. 2:349-72.

GIFFORD, E. M., JR.

1951. Early ontogeny of the foliage leaf in Drimys winteri var. chilensis. Amer. Jour. Bot. 38:93-105.

1953. Effect of 2,4-D upon the development of the cotton leaf. Hilgardia 21:606-44.

Girolami, G.

1954. Leaf histogenesis in Linum usitatissium. Amer. Jour. Bot. 41:264-73.

1955. Comparative anatomical effects of the curly-top and aster-yellows viruses on the flax plant. Bot. Gaz. 116:305-22.

Gunning, B. E. S., J. S. Pate, and L. G. Briarty

1968. Specialized "transfer cells" in minor veins of leaves and their possible significance in HARA, N. phloem translocation. Jour Cell Biol. 37:C7-C12.

1957. On the types of the marginal growth in dicotyledonous foliage leaves. Bot. Mag. Tokyo 70:108-14.

1958. Structure of the vegetative shoot apex and development of the leaf in the Ericaceae and their allies. Jour. Fac. Sci., Univ. Tokyo, Sect. III, 7:367-450.

Hibino, H., and H. SCHNEIDER

1970. Mycoplasma-like bodies in sieve tubes of pear trees affected with pear decline. Phytopathology 60 (3):499-501. 
HoEFerT, L. L., and E. M. GIFFORD, JR.

1967. Grapevine leafroll virus-history and anatomic effects. Hilgardia 38(11):403-26.

HOOPER, G. R., and H. SCHNEIDER

1969. The anatomy of tumors induced on citrus by citrus vein-enation virus. Amer. Jour. Bot. $56: 238-47$.

Jensen, W. A.

1962. Botanical histochemistry. W. H. Freeman and Company: San Francisco and London. $408 \mathrm{pp}$.

MacDaniels, L. H., and F. F. CowerT

1944. The development and structure of the apple leaf. Cornell Univ. Agr. Exp. Sta. Mem. 258:1-29.

MAKSYMOWYCH, R., and R. O. ERICKSON

1960. Development of the lamina in Xanthium italicum represented by the plastochron index. Amer. Jour. Bot. 47:451-59.

NASU, S., D. D. JENSEN, and J. Richardson

1970. Electron microscopy of mycoplasma-like bodies associated with insects and plant hosts of peach Western X-disease. Virology 41:583-95.

Pray, T. R.

1955. Foliar venation of angiosperms. II. Histogenesis of the venation of Liriodendron. Amer. Jour. Bot. 42:18-27.

QUANJER, H. M.

1931. The methods of classification of plant viruses, and an attempt to classify and name potato viruses. Phytopathology 21:577-613.

REIMER, F. C.

1925. Blight resistance in pears and characteristics of pear species and stocks. Oregon Agr. College: Exp. Sta. Bul. 214.99 pp.

REHDER, A.

1927. Manual of cultivated trees and shrubs. The MacMillan Co.: New York. 930 pp.

SchNEIDER, $\mathrm{H}$.

1945a. The anatomy of peach and cherry phloem. Bull. Torrey Bot. Club 72:137-56.

1945b. Anatomy of buckskin-diseased peach and cherry. Phytopathology 35:610-35.

1959. In: Citrus virus diseases. (J. M. Wallace, ed.) The anatomy of tristeza-virus-infected citrus. Univ. of Calif. Div. Agr. Sci., pp. 73-84.

1968. Anatomy of greening-diseased sweet orange shoots. Phytopathology 58:1155-60.

1970. Graft transmission and host range of the pear decline causal agent. Phytopathology $60(2): 204-07$.

SCHNEIDER, $\mathbf{R}$.

1952. Histogenetische Untersuchungen über den Bau der Laubblätter, insbesondere ihres Mesophylls. österreich. Bot. Zeitschr. 99:245-85.

SHIH, C. Y., and H. B. CuRRIER

1969. Fine structure of phloem cells in relation to translocation in the cotton seedling. Amer. Jour. Bot. 56:464-72.

SHTROMberg, A. Y.

1959. Cambial activity in leaves of several woody dicotyledonous plants. Akad. Nauk. SSSR (Proc. Bot. Sci., AIBS) 124:4-7.

Tsao, Pamela W., H. Schneider, and G. H. Kaloostian

1966. A brown leaf-vein symptom associated with greenhouse-grown pear plants infected with pear decline virus. Plant Dis. Rep. 50:270-74.

Tsao, Pamela W., and H. Schneider

1967. Pathological anatomy of pear tissues sensitive to pear-decline virus. Phytopathology 57: p. 103.

Wooding, F. B. P., and D. H. Northcote

1965. The fine structure and development of the companion cell of the phloem of Acer pseudoplatanus. Jour. Cell Biol. 24:117-28.

WRISCHER, MERCEDES

1965. Elektronenmikroskopische Untersuchungen der Zellnekrobiose. Protoplasma 60:355-400. 


from parenchyma cells. While the metaphloem is still functional, the cambium produces radially arranged rows of phloem mother cells. Single tiers or rows of phloem tissue form when the mother cells differentiate directly into parenchyma cells and sieve elements with associated companion cells; the latter cells require an anticlinal division of a mother cell. Two tiers of phloem tissue form from one row of phloem mother cells when the mother cells divide anticlinally before differentiating into the tiers of phloem tissue.

Necrosis of sieve tubes and companion cells in the secondary phloem occurs in diseased lateral veins. Necrosis does not occur in the primary phloem of new shoots that form following chilling; possibly they are pathogen free.

Necrosis in secondary phloem is accompanied by excessive and prolonged abnormal phloem formation, and groups of sieve tubes in this abnormal phloem become necrotic.

In sieve tubes and companion cells, the necrotic process consists of degeneration of organelles, membranes, and ground cytoplasm. Ultimately the protoplasts consist of only ribosome-like structures in an otherwise structureless mass.

Research for this paper preceded and served as a basis for another research from which it was reported that mycoplasma-like bodies are associated with the phloem of lateral veins of pear declinediseased leaves. Occasional mycoplasma-like bodies were later observed in electronmicrographs taken for the work reported herein. 
The journal HILGARDIA is published at irregular intervals, in volumes of about 650 to 700 pages. The number of issues per volume varies.

Single copies of any issue may be obtained free, as long as the supply lasto; please request by volume and issue number from:

\author{
Agricultural Publications \\ University Hall \\ University of California \\ Berkeley, California 94720
}

The limit to nonresidents of California is $\mathbf{1 0}$ separate titles. The limit to California residents is $\mathbf{2 0}$ separate titles.

The journal will be sent regularly to libraries, schools, or institutions in one of the following ways:

1. In exchange for similar published material on research.

2. As a gift to qualified repository libraries only.

3. On a subscription basis $\$ 7.50$ a year paid in advance. All subscriptions will be started with the first number issued during a calendar year. Subseribers starting during any given year will be sent back numbers to the first of that year and will be billed for the ensuing year the following January. Make checks or money orders payable to The Regents of The University of California; send payment with order to Agricultural Publications at above addrees. 